\title{
Recent Progresses and Development of Advanced Atomic Layer Deposition towards High-Performance Li-Ion Batteries
}

\author{
Wei Lu ${ }^{\dagger}$, Longwei Liang ${ }^{\dagger}$, Xuan Sun, Xiaofei Sun, Chen Wu, Linrui Hou, Jinfeng Sun and \\ Changzhou Yuan*
}

School of Material Science and Engineering, University of Jinan, Jinan 250022, China; ym0808@sohu.com (W.L.); llw198611@163.com (L.L.); 13583131953@163.com (X.S.); Asunxf_ME@163.com (X.S.);

zzwuchen@126.com (C.W.); houlr629@163.com (L.H.); sunjinfeng2010@163.com (J.S.)

* Correspondence: mse_yuancz@ujn.edu.cn; Tel./Fax: +86-531-8276-9410

† These authors contributed equally to this work.

Received: 31 August 2017; Accepted: 26 September 2017; Published: 14 October 2017

\begin{abstract}
Electrode materials and electrolytes play a vital role in device-level performance of rechargeable Li-ion batteries (LIBs). However, electrode structure/component degeneration and electrode-electrolyte sur-/interface evolution are identified as the most crucial obstacles in practical applications. Thanks to its congenital advantages, atomic layer deposition (ALD) methodology has attracted enormous attention in advanced LIBs. This review mainly focuses upon the up-to-date progress and development of the ALD in high-performance LIBs. The significant roles of the ALD in rational design and fabrication of multi-dimensional nanostructured electrode materials, and finely tailoring electrode-electrolyte sur-/interfaces are comprehensively highlighted. Furthermore, we clearly envision that this contribution will motivate more extensive and insightful studies in the ALD to considerably improve Li-storage behaviors. Future trends and prospects to further develop advanced ALD nanotechnology in next-generation LIBs were also presented.
\end{abstract}

Keywords: atomic layer deposition; electrode materials; solid-state electrolytes; electrode-electrolyte sur-/interfaces; Li-ion batteries

\section{Introduction}

Nowadays, the wide application of electric vehicles (EV) and hybrid EV may be one of the best approaches to reduce the continuous consumption of traditional fossil fuels, which can alleviate the deepening crises about climate change and air pollution. The critical challenge for high-powered electric transportation is the exploitation of high-performance energy storage devices with high power and energy densities, and high reliability [1-3]. Lithium-ion batteries (LIBs) thus have been regarded as one of ideal power supplies, thanks to their overwhelmingly high volumetric/gravimetric energy densities along with other superiorities including affordable price, long cycle life, and environmental friendliness [4-6]. Typically, as shown in Figure 1, a LIB cell consists of a lithium metal oxide cathode (positive electrode, e.g., $\mathrm{LiCoO}_{2}$ ), a carbon anode (negative electrode, e.g., graphite), an electronically insulating separator, and an ionically conductive $\mathrm{Li}^{+}$-containing electrolyte [1]. During the charging process, $\mathrm{Li}^{+}$ions commonly migrate from the cathode structure, transport through the electrolyte, and finally intercalate into the anode. Concurrently, the electrons flow from the cathode to anode through an outer circuit. Upon a reversible discharging process occurring, so-called the rocking chair batteries, LIBs rely on the shuttling of lithium-ions back and forth between the two electrodes during charge-discharge cycles. Consequently, the employed electrode materials intensely govern both cell voltage and specific capacity of LIBs. 


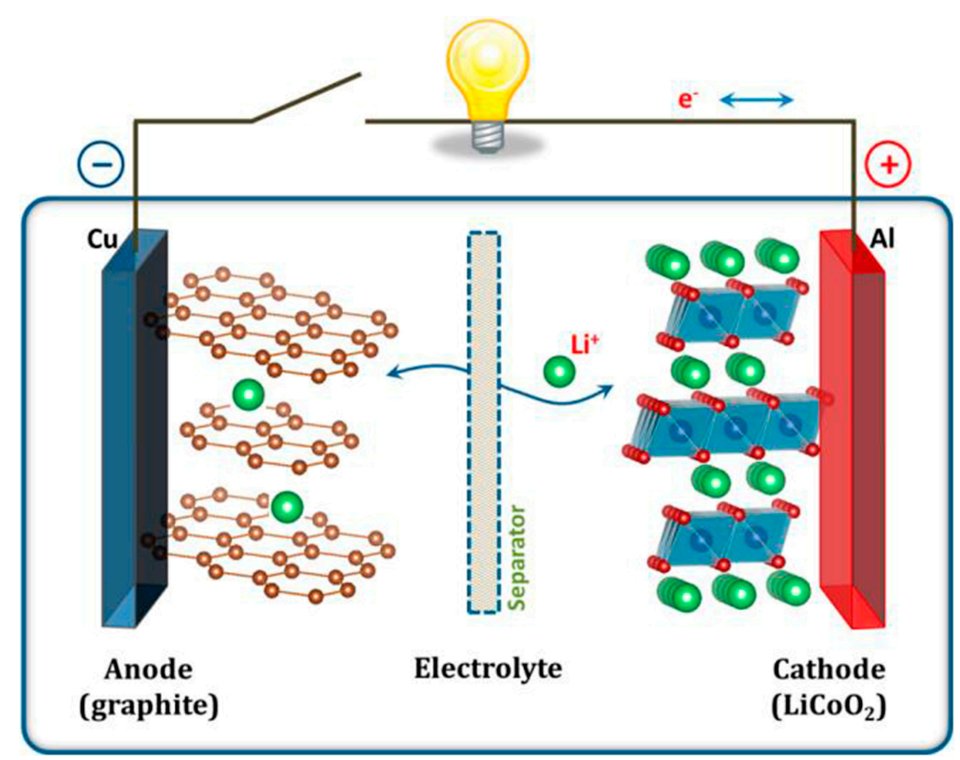

Figure 1. Schematic illustration for working mechanism of rechargeable lithium-ion batteries (LIBs). Reprinted with permission from Ref. [1] @copyright 2013 American Chemical Society.

To this end, electrode materials to fulfill high safety, large capacity, and long cycle lifetime are being developed by collaborative efforts in universities, national labs and industries around the world $[7,8]$. As widely demonstrated, conventional layered $\mathrm{Li}_{1-x} \mathrm{CoO}_{2}(\mathrm{LCO})$ is distressfully trapped in the phase distortion from monoclinic to hexagonal phase during the repeated charge-discharge process particularly when $x>0.5$, which greatly limits the practical capacities of the LCO cathodes with merely half of its theoretical capacity $[9,10]$. Although $\mathrm{Ni}$-based cathodes, such as $\mathrm{LiNi}_{1 / 3} \mathrm{Mn}_{1 / 3} \mathrm{Co}_{1 / 3} \mathrm{O}_{2}$ (NMC333), $\mathrm{LiNi}_{0.8} \mathrm{Mn}_{0.1} \mathrm{Co}_{0.1} \mathrm{O}_{2}$ (NMC811), $\mathrm{LiNi}_{0.6} \mathrm{Mn}_{0.2} \mathrm{Co}_{0.2} \mathrm{O}_{2}$ (NMC662), $\mathrm{LiNi}_{0.5} \mathrm{Mn}_{0.3} \mathrm{Co}_{0.2} \mathrm{O}_{2}$ (NMC532), and so on, offer an integration of high reversible capacity, high operating voltage and acceptable chemical stability. However, they still seriously suffer from the interfacial structural degeneration (layered-spinel-(rock-salt)) and are terribly sensitive to the humidity (Li-containing impurities deposited) [11-13]. Within the group of layered cathodes, Li-rich layered oxides (LLOs) have attracted plenty of attention owing to their large capacities $\left(250-300 \mathrm{mAh} \cdot \mathrm{g}^{-1}\right)$. Unfortunately, the oxygen loss from the lattice during the initial charge and the incident migration of the manganese occurs from the transition-metal plane to the lithium plane. It leads to high irreversible capacity loss in the first cycle, substantial voltage decay upon cycling and inferior rate capability, which enormously hinders the commercial application of the LLOs in LIBs $[14,15]$. As for spinel cathodes, such as $\mathrm{LiMn}_{2} \mathrm{O}_{4}$, it is also tremendously restricted in consequence by the limited discharge capacities $\left(\sim 120 \mathrm{mAh} \cdot \mathrm{g}^{-1}\right)$ and unsatisfactory high-temperature electrochemical properties caused by the critical issues stemming from the Jahn-Teller distortion, manganese dissolution and oxygen deficiency $[16,17]$. Equally, the anode materials employed in LIBs also play a significant role, while it is still confronted with various troubles. As is well known, Li metal was once regarded as one of the most promising anode materials for beyond Li-ion batteries owing to its low electrochemical potential and high theoretical specific capacity $\left(\sim 3861 \mathrm{mAh} \cdot \mathrm{g}^{-1}\right)$. However, the formation of harmful dendrites on its surface together with the unstable Li-electrolyte interface extremely reduces the widely commercial application of the metal lithium $[18,19]$. Other potential anode materials including, but not limited to, $\mathrm{Li}_{4} \mathrm{Ti}_{5} \mathrm{O}_{12}$ and $\mathrm{Si}$ are also faced with other troublesome obstructions: intrinsic low electrical conductivity and lithium diffusion co-efficient for spinel $\mathrm{Li}_{4} \mathrm{Ti}_{5} \mathrm{O}_{12}$, and for the $\mathrm{Si}$ anode, huge stresses coupled with drastic volume expansion during lithiation, and fracture and/or contact loss of the electroactive Si over cycling [20-23]. Hence, intensive research should be conducted to figure out the origin of structural evolution and to explore effective approaches to completely mitigate or eradicate the critical issues mentioned above. 
Facing these challenges in LIBs, worldwide researchers devote themselves to seeking effective solutions, ranging from various nanostructured electrode materials, component optimization, novel cell configuration design, and so on [24-28]. Among these choices, surface coating of electrode materials already has been widely demonstrated to significantly improve the electrochemical properties of LIBs. Different types of coating materials, depending on the inherent feature of electrodes themselves, have been adopted and generalized [29-32]. Nevertheless, it is universally recognized that the adopted coating route plays a significant role in the ultimate performance of LIBs. Although traditional strategies, including mechanical mixing [9,31,33,34], sol-gel method [11,35-37] and hydrolysis-precipitation [19,29], have been developed greatly, these approaches cannot build an intact, homogeneous, steady yet thickness-controllable coating layer on the bulk electrode. Especially, the coating particles just disperse randomly on the surface by mechanical mixing method because no intermolecular forces get involved. Additionally, as for the sol-gel method, due to the heterogeneously distributed coating raw materials and the limited fluid dynamics, the thickness of the coating layer is greatly difficult to be uniform.

In conquering these upsetting issues, a promising strategy, called atomic layer deposition (ALD), has been an extensively researched hotspot, benefitting from its multifunctional capabilities and exceptional characteristics [38-45]. By virtue of the ALD technology, various elaborate nanostructured electrode materials including cathodes and anodes have been successfully fabricated and, more significantly, high aspect ratio conformity and high controllability of the thickness, composition and crystalline can be easily realized [46-50]. Consequently, the mass transfer diffusion and/or reaction kinetics, structural stability, and practical energy density of the ALD-fabricated materials will be substantially enhanced.

Stimulated by the ever-increasingly application of the smart ALD in LIBs, we summarized here the up-to-date progress and development of the ALD technique in advanced LIBs in view of the ever-expanding research. Following the introductory section, the working mechanisms and characteristics of the ALD are briefly presented. The elegant electrode-electrolyte sur-/interface engineering based on the ALD brings outstanding synergistic effects to the structural stability and electrochemical properties of electrode materials and solid-state electrolytes (SSEs). Thus, the latest progress and development of the ALD to optimize the sur-/interfacial surroundings of both cathodes and anodes are highlighted and specified in the third part. Finally, we outline the remarkable significance of the ALD in next-generation LIBs together with its potential utilizations in LIBs for future studies.

\section{Brief Description of the ALD Method}

The term "ALD" is originally dated from a technique called "atomic layer epitaxy" that was used to deposit $\mathrm{ZnS}$ for flat panel displays, and then greatly propelled under the background of booming semiconductor devices in consequence of the urgent requirement of continuous and pinhole-free films [43]. Following this, nowadays, appealing ALD has been widely recognized as a competitive approach to construct various types of materials and structures for many advanced and/or new studies and industry fields by virtue of its exceptional properties [38,51,52]. The surface chemistry, detailed mechanisms, and striking features including low growth temperature, atomic-scale and stoichiometric deposition, excellent uniformity and conformity peculiar to the ALD has been thoroughly summarized by Sun [41], George [53] and Zaera [54], et al. Multitudinous ALD-assisted applications have been presented in-depth by Puurunen [55], Gregorczyk [56] and co-workers. In general, the ALD goes on in a repeating manner, which depends on self-limiting, irreversible, and separated gas-solid surface reactions requiring typically at least two compounds. One should note that substrates, temperatures and precursors are the three crucial factors determining the final deposition features. Figure 2 illustrates the most representative yet successful ALD procedures for the ALD-depositing $\mathrm{Al}_{2} \mathrm{O}_{3}$ film by using trimethylaluminum (TMA) and water as precursors. In the first step (a), the precursor of the TMA reacts with the surface hydroxyl groups via self-limiting chemisorption to form a monolayer. The obtained 
surface is particularly reactive to the subsequent molecule, $\mathrm{H}_{2} \mathrm{O}$, which forms a second monolayer in the following step (b). Thus, one cycle deposits one monolayer of the compound $\mathrm{Al}_{2} \mathrm{O}_{3}$ and regenerates the initial substrate with hydroxyl groups. By repeating the two reactions in sequence, the $\mathrm{Al}_{2} \mathrm{O}_{3}$ thin films can be grown with atomic precision and uniformity on planar, nonporous, or porous materials. More encouragingly, the ALD technique with high aspect ratio conformity and precise controllability of thickness, composition and crystalline is undoubtedly appealing for the preparation of nanostructured materials of rigorous geometry and composition, which only takes a few minutes. Furthermore, the ALD surface modification with no any additional detrimental reactant endows more uniform surface coverage than conventional wet chemistry methods. Thus, the ALD is deductively easy to scale up for industry-level applications in LIBs. Up to now, the ALD has been incessantly explored as an alternative approach to synthesize cathode and anode materials, as well as SSEs utilized in rechargeable energy applications, such as LIBs, lithium-sulfur batteries [57,58], sodium-ion batteries [59-61], lithium- $\mathrm{O}_{2}$ batteries [62], supercapacitors [63,64], solar cells [65], and so on. Especially in this review, we intensively focus on the up-to-date achievements of the ALD in synthesizing, modifying, stabilizing the electrodes and tailoring the electrode-electrolyte sur-/interfaces for high-performance LIBs.

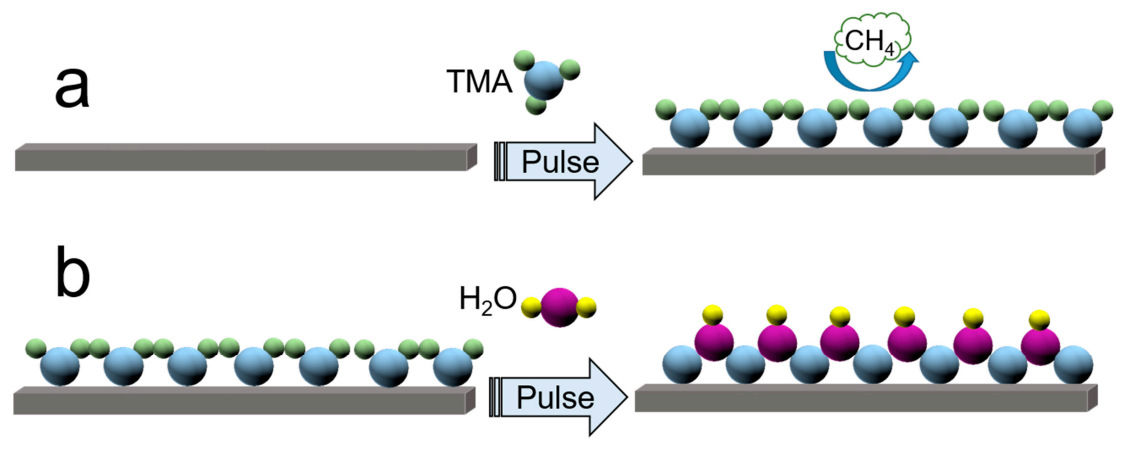

Figure 2. A model illustration for the atomic layer deposition (ALD) depositing $\mathrm{Al}_{2} \mathrm{O}_{3}$ on hydroxyl groups functionalized substrate including step (a) and step (b) by using the trimethylaluminum (TMA) and water as reactants.

\section{Construction of Electrode Materials and SSEs via the ALD Methodology}

The contributions offered by nanostructured electrode materials can be summarized as follows: (i) enhanced cyclic stability; (ii) higher rate capability benefitted from the shorter diffusion path for $\mathrm{Li}^{+}$ions and electrons; and (iii) less possibility of parasitic reactions with the bulk materials. Notably, the ALD has distinct advantages, such as thin-film thickness control at the atomic scale and excellent conformity, which are essential to realize electrode materials at nanoscale [66]. However, the nanostructured electrode still possesses some shortcomings, for instance, unsatisfactory processability caused by the large specific surface area (SSA), lower volumetric energy densities, and more complicated synthetic processes. Although nanomaterials synthesis and surface coating via the ALD have made a great amelioration for the aforementioned issues, the low ionic conductivity of conventional ALD coating materials is still an urgent problem to be solved. Fortunately, the SSEs can efficiently solve this challenge and conquer the dissolution puzzles [41,42]. Table 1 selectively summarizes the up-to-date anode and cathode materials, and SSEs constructed via the ALD. 
A typical representative of TMOs-based anodes combining carbonaceous materials is amorphous $\mathrm{TiO}_{2}$ deposited on CNTs network/carbon fiber paper (CFP) substrates via the ALD at $120^{\circ} \mathrm{C}$, where the $\mathrm{TiCl}_{4}$ and water as the titanium and oxygen source, respectively [75]. The formed three-dimensional (3D) hierarchical $\mathrm{TiO}_{2} @ \mathrm{CNTs} / \mathrm{CFP}$ is shown in Figure 3a-c. Another analogous study was conducted by Fan et al. [104], where a thin $\mathrm{TiO}_{2}$ layer is deposited on the 3D hierarchical carbon nanowire (NW) array with mechanical robustness and flexibility. Apart from the 3D supports, Alshareef and co-workers recently reported the $\mathrm{SnO}_{2}$ grown on two-dimensional (2D) titanium carbide (MXene) sheets by the ALD, as exhibited in Figure 3d-f, and further utilized the $\mathrm{SnO}_{2} / \mathrm{MXene}$ composite anode for LIBs. These diversities in morphology and crystallinity can be attributed to be the variation in the surface functional groups and reaction mechanisms with different deposition parameters [105]. As expected, superior electrochemical performance is appealingly observed. As shown in Figure $3 g$, the outstanding Li-storage properties have been achieved for the amorphous $\mathrm{TiO}_{2} @ \mathrm{CNTs} / \mathrm{CFP}$ anode, exhibiting high reversible capacity $\left(\sim 272 \mathrm{mAh} \cdot \mathrm{g}^{-1}\right.$ at $\left.0.1 \mathrm{~A} \cdot \mathrm{g}^{-1}\right)$, superior rate capability $\left(\sim 133 \mathrm{mAh} \cdot \mathrm{g}^{-1}\right.$ at $\left.40 \mathrm{~A} \cdot \mathrm{g}^{-1}\right)$ and ultralong cycling performance $\left(\sim 93 \%\right.$ capacity retention after 10,000 cycles at $\left.20 \mathrm{~A} \cdot \mathrm{g}^{-1}\right)$. Similarly, as shown in Figure $3 \mathrm{~h}$, the $\mathrm{SnO}_{2} / \mathrm{MXene}$ anode exploits a stable discharge capacity of $\sim 843 \mathrm{mAh} \cdot \mathrm{g}^{-1}$, and retains the mechanical and structural integrity of the 2D conductive MXenes platform meanwhile. The excellent Li-storage properties based on the 2D and/or 3D carbon materials can be put down to its structural uniqueness, which shortens the ionic diffusion length, buffers the volume changes, and supports large SSA for repeated $\mathrm{Li}^{+}$-insertion/extraction reactions.

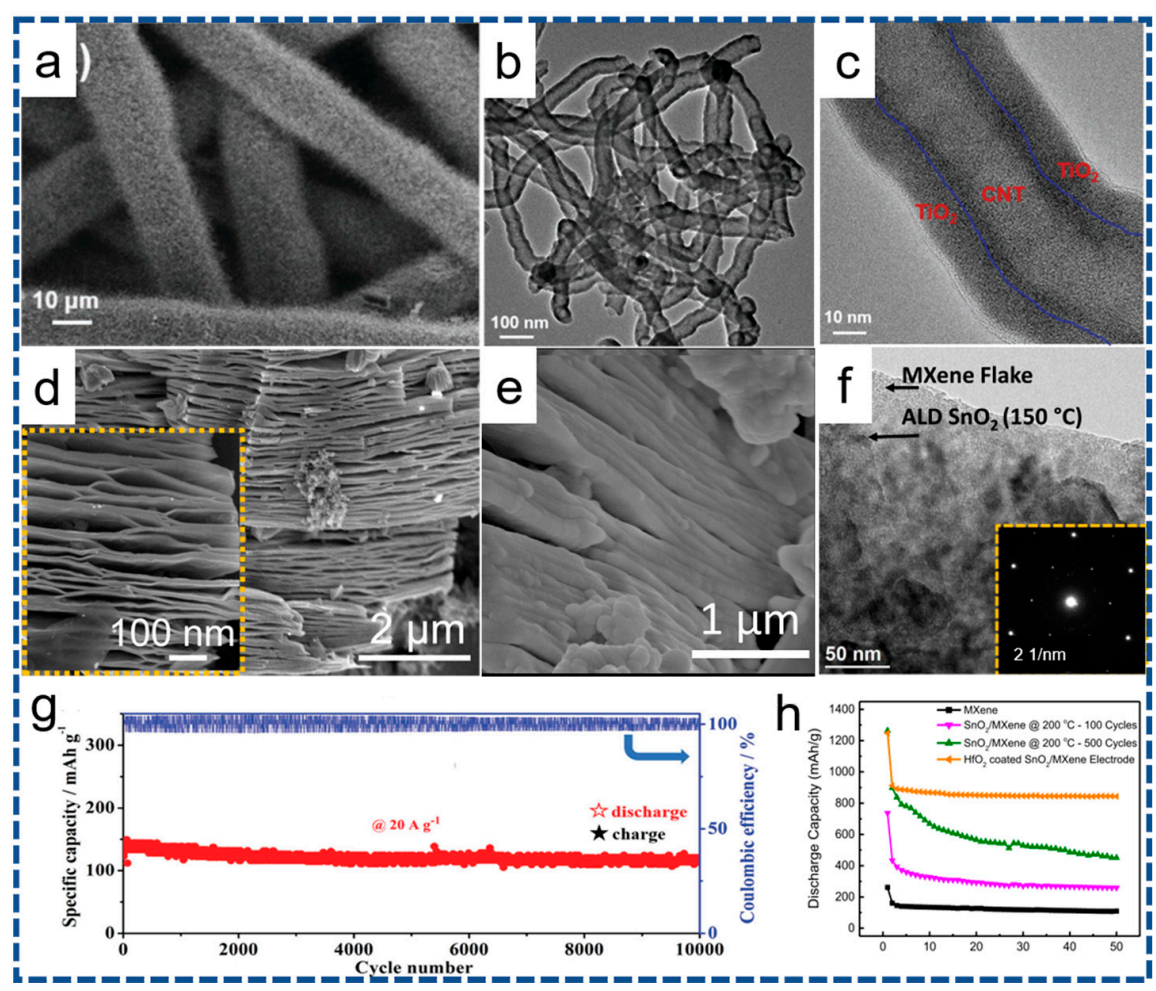

Figure 3. Typical anode materials fabricated via the ALD on carbonaceous supports. (a) Field emission scanning electron microscope (FESEM) and $(\mathbf{b}, \mathbf{c})$ Transmission electron microscope (TEM) images of $\mathrm{TiO}_{2} @ \mathrm{CNTs} / \mathrm{CFP}$. Scanning electron microscope (SEM) images of (d) HF-etched $\mathrm{Ti}_{3} \mathrm{C}_{2}$ MXene and (e) $\mathrm{SnO}_{2}$-coated MXene anode, (f) TEM analysis of MXene sheets coated with a 50-nm-thick layer of $\mathrm{SnO}_{2}$ and selected area electron diffraction (SAED) pattern (the inset). (g) Cycling performance at $20 \mathrm{~A} \mathrm{~g}^{-1}$ for 10,000 cycles for $\mathrm{TiO}_{2} @ \mathrm{CNTs} / \mathrm{CFP}$. (h) Cyclic performance over 50 cycles at $500 \mathrm{~mA} \cdot \mathrm{g}^{-1}$ of $\mathrm{SnO}_{2} / \mathrm{MXene}$ and $\mathrm{HfO}_{2}$ coated $\mathrm{SnO}_{2} / \mathrm{MXene}$ electrodes. (a-c,g) reprinted with permission from Ref. [75] @copyright 2016 Wiley. (d-f,h) reprinted with permission from Ref. [70] @copyright 2017 Elsevier. 
Benefitting from these unique carbonaceous supports, several other types of 2D/3D nanostructures-based anodes fabricated by the ALD have been reported, such as, $\mathrm{Li}_{4} \mathrm{Ti}_{5} \mathrm{O}_{12} @$ graphene nanosheets (GNs) [82], $\mathrm{RuO}_{2} @ M W C N T$ [67], $\mathrm{TiO}_{2} @ G N s$ [76], $\mathrm{TiO}_{2} /$ carbon black [78], $\mathrm{WS}_{2} @ M W C N T$ [83], WN $\mathrm{N}_{x} @ \mathrm{CNTs}$ [85]. Apart from carbon-based matrixes, 3D nanoporous gold substrates was further applied for the $\mathrm{TiO}_{2}$ deposition [80], where large pore size is essential for $\mathrm{Li}^{+}$diffusion, particularly at high rates. Additionally, electroactive $\mathrm{SnO}_{2}$ was conformally deposited on Ni nanofoam [68], where both large SSA and high conductivity are proved to contribute more electroactive sites for fast electrochemical reaction. As a result, the obtained $\mathrm{SnO}_{2} / \mathrm{Ni}$ nanofoam anodes show even higher capacities and better cycling ability. Furthermore, thin film anodes $\left(\mathrm{MoN}_{x}[84]\right.$ and LiTP [86]) directly prepared via the ALD are also significantly developed, and demonstrate highly stable structures and outstanding rate capability. Therefore, we have strong evidence to believe that the smart combination of the tunable thickness/mass of thin-layer electroactive phases and carbonaceous matrixes with superior electronic conductivity and large SSA has been shown very promising for high-performance energy storage devices.

\subsection{Cathodes via the ALD}

Owing to the exceptional reaction-controlled deposition process utilized by the ALD, it can deposit homogeneous and conformal thin films on substrates with high-aspect-ratio topography, and provide high flexibility for tuning the thickness, size, and composition of target materials at the atomic scale $[48,106]$. Thus, several unique yet beneficial characteristics of ultrathin materials grown by the ALD for electrochemical energy storage are anticipated to be observed. Actually, just several cathodes fabricated by the ALD have been investigated for LIBs so far, such as non-lithiated cathodes $\left(\mathrm{V}_{2} \mathrm{O}_{5}\right.$ [87-90] and $\mathrm{FePO}_{4}$ [91]), and lithiated cathodes including $\mathrm{LiFePO}_{4}$ [48], $\mathrm{LiCoO}_{2}$ [92] and $\mathrm{Li}_{x} \mathrm{Mn}_{2} \mathrm{O}_{4}$ [93].

$\mathrm{V}_{2} \mathrm{O}_{5}$, as the cathode material for LIBs, can be easily obtained via the ALD with no need for any thermal post-treatment. Lately, a 3D multi-hierarchical $\mathrm{TiO}_{2} / \mathrm{V}_{2} \mathrm{O}_{5} / \mathrm{CNTs}$ paper electrode has been investigated by $\mathrm{Xie}$ and co-workers [90], where amorphous $\mathrm{V}_{2} \mathrm{O}_{5}$ and ultrathin $\mathrm{TiO}_{2}$ are deposited on the CNTs paper by utilizing VOTP and $\mathrm{H}_{2} \mathrm{O}$, and $\mathrm{TiCl}_{4}$ and $\mathrm{H}_{2} \mathrm{O}$ as precursors. Typical SEM and TEM images of the as-fabricated $\mathrm{TiO}_{2} / \mathrm{V}_{2} \mathrm{O}_{5} / \mathrm{CNTs}$ are displayed in Figure $4 \mathrm{a}, \mathrm{b}$. It can be observed that no agglomerated particles can be detected after ALD deposition, implying that $\mathrm{TiO}_{2}$ and $\mathrm{V}_{2} \mathrm{O}_{5}$ thin films are both uniformly anchored on the surface of CNTs. This distinctive $\mathrm{TiO}_{2} / \mathrm{V}_{2} \mathrm{O}_{5} / \mathrm{CNTs}$ electrode yields a discharge capacity of $\sim 400 \mathrm{mAh} \cdot \mathrm{g}^{-1}$ at $100 \mathrm{~mA} \cdot \mathrm{g}^{-1}$, as shown in Figure $4 \mathrm{c}$, approaching the theoretical value of the $\mathrm{V}_{2} \mathrm{O}_{5}$. More significance of this work is that the dissolution problem of vanadium cathodes has been substantially resolved by the $\mathrm{TiO}_{2}$ coating. Another non-lithiated cathodes synthesized via the ALD is amorphous $\mathrm{FePO}_{4}$ [91]. Sun et al. develops a non-aqueous approach to deposit iron phosphate cathode materials on nitrogen-doped carbon nanotubes (NCNTs) by combining ALD subcycles of the $\mathrm{Fe}_{2} \mathrm{O}_{3}$ (ferrocene-ozone) and $\mathrm{PO}_{x}$ (trimethyl phosphate-water) at temperatures between $200-350{ }^{\circ} \mathrm{C}$ [91]. Corresponding SEM, TEM images, and cyclic stability of the $\mathrm{FePO}_{4} / \mathrm{NCNTs}$ are depicted in Figure $4 \mathrm{~d}-\mathrm{f}$, respectively. Evidently, the $\mathrm{FePO}_{4} / \mathrm{NCNTs}$ cathode delivers a discharge capacity of $\sim 177 \mathrm{mAh} \cdot \mathrm{g}^{-1}$ when evaluated as a cathode material for LIBs. The amorphous $\mathrm{FePO}_{4}$ fabricated by the ALD is expected to be applied in conventional LIBs and all solid-state thin film batteries as a surface-modification material. The most intriguing advancement in ALD cathodes is the synthesis of $\mathrm{LiFePO}_{4}$ on conductive CNTs as a high-performance cathode for LIBs, recently reported by Sun et al. [48]. TEM images of the $\mathrm{LiFePO}_{4} / \mathrm{CNTs}$ are shown in Figure $4 \mathrm{~g}$,h, which confirms the uniformity of the as-deposited $\mathrm{LiFePO}_{4}$ layer with thickness of about $33 \mathrm{~nm}$ on the CNTs. The corresponding electrochemical properties are provided in Figure 4i. Furthermore, the conforming representative ALD sequence of $5 \times\left(\mathrm{FeCp}_{2}-\mathrm{O}_{3}-\mathrm{TMPO}-\mathrm{H}_{2} \mathrm{O}\right)+1 \times\left(\mathrm{LiO}^{\mathrm{t}} \mathrm{Bu}-\mathrm{H}_{2} \mathrm{O}\right)$ is exhibited in Figure 5. Impressively, a high capacity of $\sim 71 \mathrm{mAh} \cdot \mathrm{g}^{-1}$ can be delivered by the $\mathrm{LiFePO}_{4} / \mathrm{CNTs}$ electrode as the current rate increases up to $60^{\circ} \mathrm{C}$. In addition, this $\mathrm{LiFePO}_{4} / \mathrm{CNTs}$ cathode owns superior capacity retention of $\sim 70.5 \%$ after 2000 cycles. The smart combination of carbon 
nanostructure and ultrathin ALD layer can be responsible for the excellent rate and cycling ability. More meaningfully, this work neatly paves the way towards purposeful fabrication of olivine $\mathrm{LiMPO}_{4}$ cathodes as a high-power cathode for next-generation LIBs.

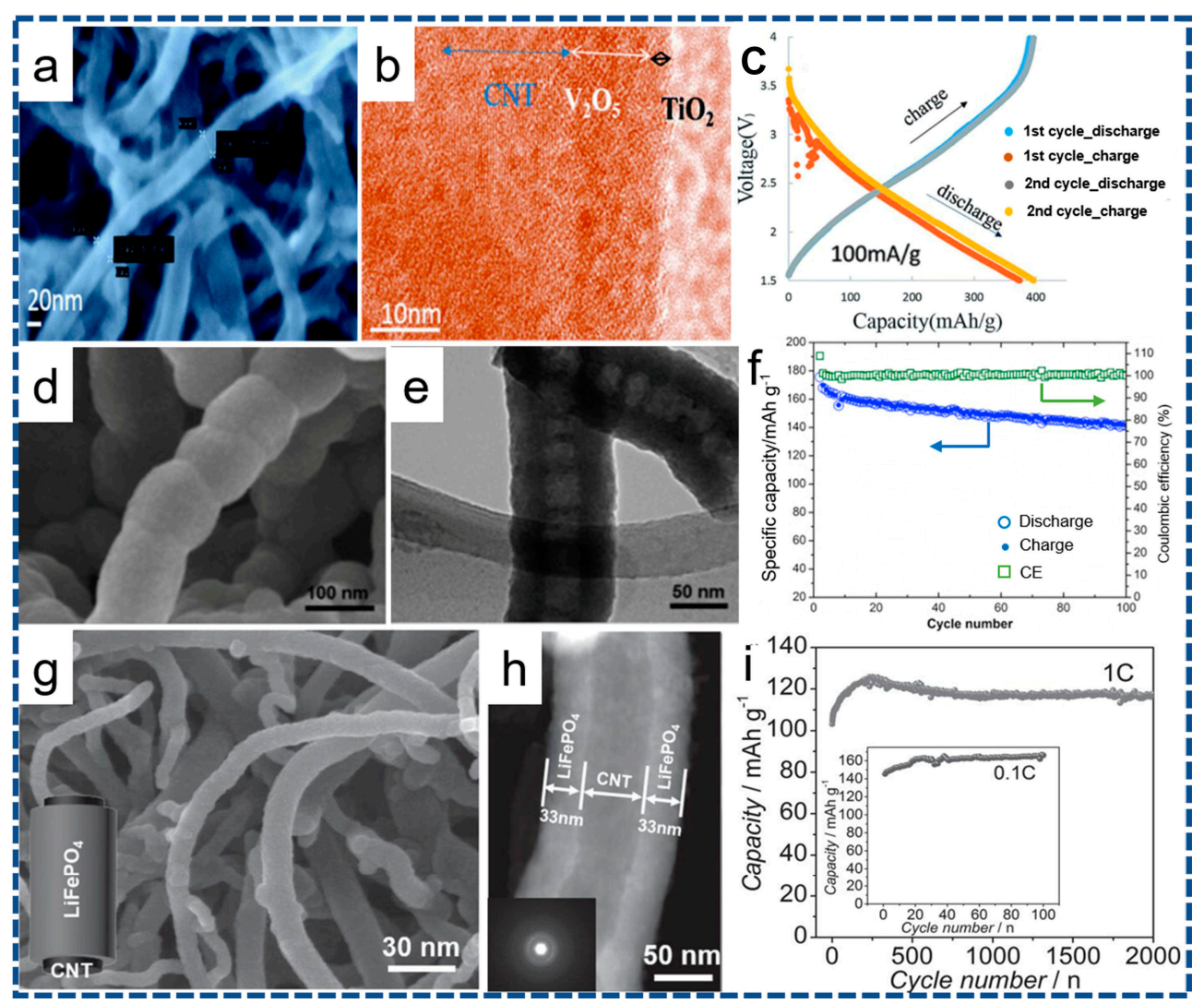

Figure 4. (a,b) SEM and TEM images of the $\mathrm{TiO}_{2} / \mathrm{V}_{2} \mathrm{O}_{5} / \mathrm{CNTs}$ paper electrode. (c) Voltage profile of the $\mathrm{TiO}_{2} / \mathrm{V}_{2} \mathrm{O}_{5} / \mathrm{CNTs}$ paper electrode for lithium ions storage. (d) SEM and (e) TEM image of the $\mathrm{FePO}_{4} / \mathrm{NCNTs}$. (f) Cycling stability of the $\mathrm{FePO}_{4} / \mathrm{NCNTs}$ at a current density of $178 \mathrm{~mA} \cdot \mathrm{g}^{-1}$. (g) SEM and (h) TEM images of the $\mathrm{LiFePO}_{4} @ \mathrm{CNTs}$. (i) Cycling performance of the LiFePO $@$ @CNTs cathode. (a-c) reprinted with permission from Ref. [90] @copyright 2016 Royal Society of Chemistry. (d-f) reprinted with permission from Ref. [91] @copyright 2015 Elsevier. (g-i) reprinted with permission from Ref. [48] @copyright 2014 Wiley.

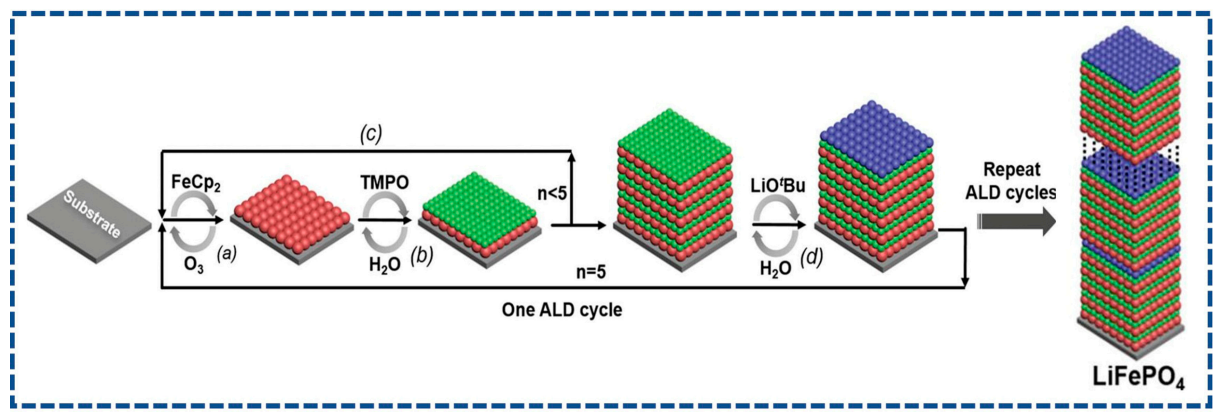

Figure 5. ALD synthesis of amorphous $\mathrm{LiFePO}_{4}$ at $300{ }^{\circ} \mathrm{C}$ using the $\mathrm{FeCp}_{2}, \mathrm{O}_{3}$, trimethylphosphate (TMPO), $\mathrm{H}_{2} \mathrm{O}$, and lithium $t$-butoxide $\left(\mathrm{LiO}^{\mathrm{t}} \mathrm{Bu}\right.$ ). (a) Sequential pulse of $\mathrm{FeCp}_{2}$ and $\mathrm{O}_{3}$ leading to the growth of a $\mathrm{Fe}_{2} \mathrm{O}_{3}$ layer (red); (b) sequential pulse of TMPO and $\mathrm{H}_{2} \mathrm{O}$ for deposition of a $\mathrm{PO}_{x}$ layer (green); (c) steps $(\mathbf{a}, \mathbf{b})$ are repeated five times; (d) sequential pulse of $\mathrm{LiO}^{\mathrm{t}} \mathrm{Bu}$ and $\mathrm{H}_{2} \mathrm{O}$ leading to formation of $\mathrm{Li}_{2} \mathrm{O}$ layer (blue). One ALD cycle for the growth of amorphous $\mathrm{LiFePO}_{4}$ consists of steps (a-d) reprinted with permission from Ref. [48]. 
The other two lithiated cathode materials, namely layered $\mathrm{LiCoO}_{2}$ [92] and spinel $\mathrm{LiMn}_{2} \mathrm{O}_{4}$ [93], which are widely applied in commercial electrical devices, also has been successfully deposited by combining a $\mathrm{Li}_{2} \mathrm{O}$ subcycle with another one or two binary oxide ALD subcycles. In order to further explore how to achieve the miniaturization of LIBs, Notten et al. [92] rationally adopts a remote plasma ALD process to fabricate $\mathrm{LiCoO}_{2}$ cathode materials from ALD subcycles of $\mathrm{Co}_{3} \mathrm{O}_{4}$ ( $\mathrm{CoCp}$-plasma $\mathrm{O}_{2}$ ) and $\mathrm{Li}_{2} \mathrm{CO}_{3}\left(\mathrm{LiO}^{\mathrm{t}} \mathrm{Bu}\right.$-plasma $\left.\mathrm{O}_{2}\right)$ in a remote plasma ALD system performed at $325{ }^{\circ} \mathrm{C}$, which is followed by calcination at $700{ }^{\circ} \mathrm{C}$ for $6 \mathrm{~min}$. Corresponding investigations manifest that the ALD-deposited $\mathrm{LiCoO}_{2}$ thin film electrodes ( $\sim 60 \%$ electroactive material) show good reversible electrochemical performance. Another significant study is the spinel $\mathrm{Li}_{x} \mathrm{Mn}_{2} \mathrm{O}_{4}$ cathode, which is obtained from $\left(\mathrm{Mn}(\mathrm{thd})_{3}-\mathrm{O}_{3}\right)$ and $\left(\mathrm{Li}(\mathrm{thd})-\mathrm{O}_{3}\right)$ subcycles at a deposition temperature of $225{ }^{\circ} \mathrm{C}$ [93]. Particularly, it is worth mentioning that this contribution provides an attractive route to transform $A L D-\mathrm{MnO}_{2}$ and $A L D-\mathrm{V}_{2} \mathrm{O}_{5}$ into $\mathrm{Li}_{x} \mathrm{Mn}_{2} \mathrm{O}_{4}$ and $\mathrm{Li}_{x} \mathrm{~V}_{2} \mathrm{O}_{5}$ by $\mathrm{Li}($ thd)/ozone and $\mathrm{LiO}^{\mathrm{t}} \mathrm{Bu}$ /water treatments, respectively. As a result, the $\mathrm{Li}_{x} \mathrm{Mn}_{2} \mathrm{O}_{4}$ fabricated via the ALD exhibits $\sim 230 \mathrm{mAh} \cdot \mathrm{g}^{-1}$ at $50 \mu \mathrm{A}$ and stable cycling performance over 1000 cycles. Remarkably, these significant results powerfully reveal that the ALD is a promising method to deposit electroactive lithium-containing electrode materials for advanced LIBs.

\subsection{SSES via the ALD}

Recently, all-solid-state LIBs are becoming hot research topics, thanks to their enhanced safety and pronounced cyclic stability. However, all-solid-state batteries are still confronted with two critical challenges including high interface resistance of the electrodes and poor ion conductivity of the SSEs themselves $[107,108]$. Benefitting from its superior capability to conformally coat the electrode surface, the ALD has been served as an alternative, promising candidate to fabricate all-solid-state thin film batteries [109]. Several papers previously reported have demonstrated the meaningful contribution of the ALD in this domain, especially solid electrolyte film functioning as a protective layer [67,100,110-114]. In fact, some SSEs prepared by the ALD have been investigated in recent studies, as summarized in Table 1, such as LiPON [94,95], $\mathrm{Li}_{7} \mathrm{La}_{3} \mathrm{Zr}_{2} \mathrm{O}_{12}$ [96], $\mathrm{Li}_{x} \mathrm{Al}_{y} \mathrm{Si}_{z} \mathrm{O}$ [97,98], $\mathrm{Li}_{x} \mathrm{Ta}_{y} \mathrm{O}_{z}$ [99], $\mathrm{Li}_{x} \mathrm{Al}_{y} \mathrm{~S}$ [100] and $\mathrm{Li}_{2} \mathrm{O}-\mathrm{SiO}_{2}$ [101]. These lithiated SSEs provide a potential platform for achieving high energy/power density, long-lasting, and safe rechargeable batteries. Typically, the ceramic oxide garnet $\mathrm{Li}_{7} \mathrm{La}_{3} \mathrm{Zr}_{2} \mathrm{O}_{12}$ (LLZO) with Al-doped reported by Dasgupta [96] for the first time is deposited at $200{ }^{\circ} \mathrm{C}$ from $\mathrm{Li}_{2} \mathrm{O}\left(\mathrm{LiO}^{\mathrm{t}} \mathrm{Bu}-\mathrm{H}_{2} \mathrm{O}\right), \mathrm{La}_{2} \mathrm{O}_{3}\left(\mathrm{LaFAMD}-\mathrm{H}_{2} \mathrm{O}\right), \mathrm{ZrO}_{2}\left(\mathrm{TDMAZ}_{2} \mathrm{H}_{2} \mathrm{O}\right)$, and $\mathrm{Al}_{2} \mathrm{O}_{3}\left(\mathrm{TMA}-\mathrm{H}_{2} \mathrm{O}\right)$ with a series of subcycles of $\mathrm{La}(\mathrm{FAMD})+\mathrm{O}_{3}, \mathrm{TDMAZ}+\mathrm{O}_{3}$, or $\mathrm{LiO}^{\mathrm{t}} \mathrm{Bu}+\mathrm{O}_{3}$. Intriguingly, this cubic LLZO SSE successfully applied to the solid-state Li-S batteries has been certified to yield an attractive specific capacity either at room temperature (RT) or at high temperatures, as well as high Coulombic efficiency (CE) and remarkable electrochemical stability [107]. Lithium silicates as another promising solid state thin films are deposited at temperatures between 225 and $300{ }^{\circ} \mathrm{C}$ by combining $\mathrm{ALD} \mathrm{Li}_{2} \mathrm{O}$ and $\mathrm{SiO}_{2}$ subcycles using $\mathrm{LiO}^{t} \mathrm{Bu}, \mathrm{TEOS}$, and $\mathrm{H}_{2} \mathrm{O}$ as precursors [101]. The investigation shows that the lithium silicate thin films can exhibit an ionic conductivity of $1.45 \times 10^{-6} \mathrm{~S} \cdot \mathrm{cm}^{-1}$ at $373 \mathrm{~K}$ due to the higher lithium concentration and lower activation energy. Therefore, with the unique superiorities to substantially decrease the internal resistance and overall battery impedance, the ALD is anticipated to exert a tremendous boost in fabricate ultrathin and functional SSEs for all-solid-state micro-batteries.

\section{Sur-/Interfacial Engineering Optimization via the ALD}

In general, the interfacial side-reactions always unavoidably emerge between the electrode and liquid electrolyte during repetitive charge-discharge process [10]. On the one hand, the tunability and controllability of the sur-/interface reactions will be tremendously beneficial to enhance the electrochemical performance of LIBs. For instance, as for the anodes, the solid electrolyte interphase (SEI) at its interface is critical to protect the bulk material from destruction and improve thermostability by preventing adverse decomposition of the $\mathrm{LiFP}_{6}$-based electrolytes containing trace water $[13,32]$. On the other hand, the interface side effects derived from the direct contact of electroactive material and 
electrolytes also can lead to a variety of unfavorable influences, particularly increasingly accumulated irretrievable damage to the cathodes, which intensely compromises the overall properties of LIBs. Moreover, these detrimental effects will be aggravated under the rigorous high cut-off voltages and high temperatures. Typically, the capacity loss in the initial discharge process mainly results from the SEI formed on the anode surface, which resulting in permanent consumption of $\mathrm{Li}^{+}$ions. As for the cathode surface, the byproducts $\left(\mathrm{Li}_{x} \mathrm{POF}_{y}, \mathrm{P}_{2} \mathrm{O}_{5}, \mathrm{LiF}\right.$, etc.) generated from the side reactions tightly adhere to the cathode surface, which highly retards the $\mathrm{Li}^{+}$transfer $[10,33,115]$. Of note, the gradually enlarged phase distortion and the dissolution of active elements are also accompanied meanwhile, which subsequently renders a sharp decline in electrochemical Li-storage performance.

In order to substantially improve the interfacial mass transportation, surface coating strategy has been widely verified to effectively address the critical issues encountered by most of the electrode materials including phase deformation, lithium-containing impurities accumulation and electroactive elements dissolution. Importantly, it is recognized that the thickness, uniformity, conductivity and stability of the coating layer is still full of challenges. As obviously shown in Figure 6a, conventional and/or improper coating routes are readily inclined to yield intermittent and scattered coating products on the host material. The exposed cathode/anode surface is unprotected when faced with the electrolytes, resulting in the poor electrochemical properties [116]. As vividly depicted in Figure 6b, constructing the desirable surface coating layer should at least satisfy the following requirements: (I) ultrathin, intact and consecutive coating layer. Ultrathin coating layer is not only conducive to the transmission of ions and electrons, but also has a positive impact on the capacity of the bulk electrode. The intact and consecutive coating layer will maximize the preservation of bulk materials and guarantee the smooth diffusion of $\mathrm{Li}^{+}$ions and electrons through the coating layer. (II) High conductivity for $\mathrm{Li}^{+}$ions and/or electrons. The coating layer of high conductivity can effectively decrease the charge transfer resistance and electrochemical polarization, thus facilitating the migration of $\mathrm{Li}^{+}$ions or electrons into/out of the bulk material. (III) Superior chemical durability. The coating layer should have superior chemical durability so as to keep off the corrosion from electrolytes, assuring the repeated charge/discharge cycles $[7,10,40]$. Therefore, the exploration for an undefective coating approach is always in progress.

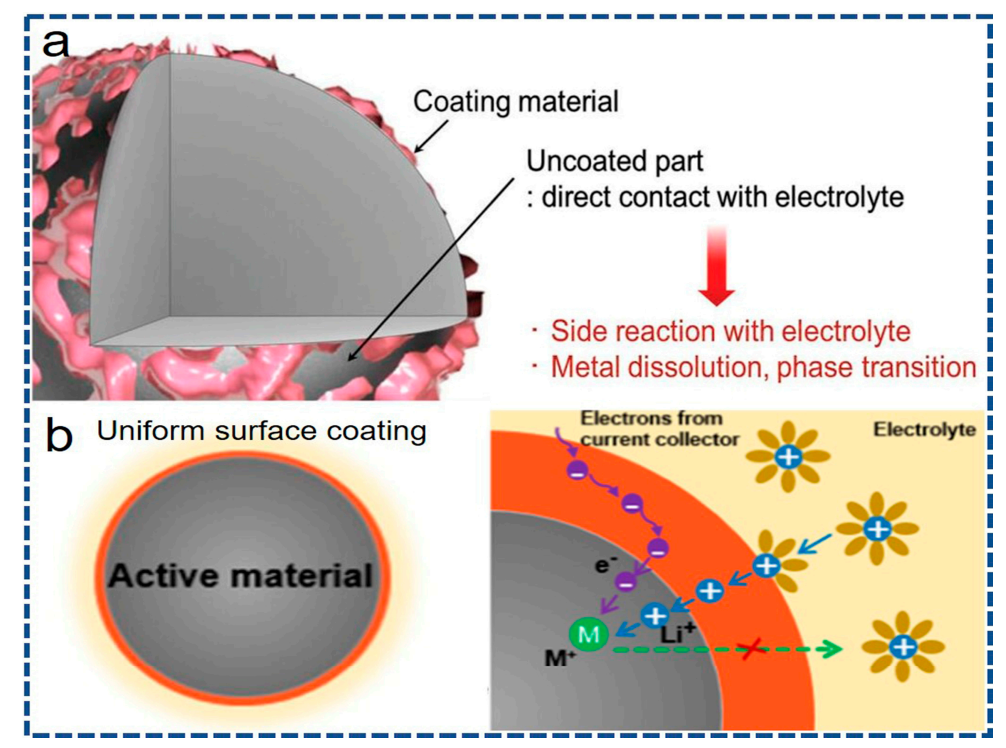

Figure 6. (a) Typical schematic views of coated surface morphologies prepared from conventional method with an uncoated part and an island-shape coating material (reprinted with permission from Ref. [116] @copyright 2014 Wiley). (b) Schematic diagram of an ideal surface coating layer on the electroactive materials (reprinted with permission from Ref. [40] @copyright 2015 IOP). 
The ALD is identified to be an extraordinary deposition technique combining atomic scale deposition performed at low operating temperatures and outstanding controllability in the thickness and dimensions of the coating layer. The ALD surface engineering on the anodes and cathodes are summarized in Tables 2 and 3, respectively. It can be easily concluded that both of structural stability and electrochemical properties of anodes and cathodes are significantly enhanced after ALD coating. Furthermore, especially in LIBs, the ALD has been utilized in various functionalities including non-conductive (mainly refer to the TMOs) and conductive (lithium-containing SSEs) surface coating for anode and cathode materials. As retrieved, the ALD coating is performed: (I) on the anodes and cathodes with one or more target materials [117-119]; (II) on the electrodes in order to protect an electronically conductive network among the electroactive materials, carbon additives, and current collectors [120-122]; (III) directly on the as-prepared powders before assembling cells [123-127]. More importantly, the whole ALD process is energy-efficient, fast (only a few minutes), no any damage to the electrodes, thus stands a chance in practical industrial applications. As a consequence, the remarkable functionality of the ALD surface coating and consequential contribution to enhance the electrochemical properties will be highlighted in this section.

\subsection{Sur-/Interfacial Engineering in Anodes via the ALD}

The ALD sur-/interfacial engineering in the anodes mainly aims to address a hard nut to crack stemming from the SEI. The formation mechanisms on anodes and the intrinsic nature of the SEI has been evaluated in-depth for LIBs $[127,128]$. The universally accepted conclusion is that the special compositions and structures are both critical factors in determining electrochemical performance and degeneration of LIBs. Especially for the $\mathrm{Si}, \mathrm{Sn}$ and $\mathrm{SiO}_{2}$ anodes, the demotivated influences derived from SEI formation aggravate intensely during the cyclic process along with large volume variation, which can damage the anodes and thus expose the fresh surface, resulting in the great loss in capacities $[123,129,130]$.

As a realistic anode candidate for commercial LIBs up to now, the graphite provides a combination of high capacity, low potential and moderate volume change [7]. However, the SEI formed on the surface starting from the first cycle gives rise to potential safety issues, particularly at high temperatures. To preserve the original surface of the graphite, the ALD has been carried out to enhance the cyclic stability and safety at elevated temperatures. Lee's group [121] directly deposits a conformal ultrathin $\mathrm{Al}_{2} \mathrm{O}_{3}$ on a graphite electrode rather than the powders. The unique $\mathrm{Al}_{2} \mathrm{O}_{3}$ film, as a protective coating shell, does not disrupt inter-particle electronic pathway at all, which consequently contributes to considerable enhancement in both long-term durability and safety. Corresponding electrochemical evaluation shows that the graphite anode with $5 \mathrm{Al}_{2} \mathrm{O}_{3}$ ALD cycles retains $\sim 98 \%$ of the initial capacity after 200 charge/discharge processes at $50{ }^{\circ} \mathrm{C}$, while the capacity of the bare counterpart dramatically fades to no more than $\sim 26 \%$ at the same cases. Another intriguing work [122] deducted that the $\mathrm{TiO}_{2}$ surface modification functions as an artificial SEI to ameliorate the stability and capability of graphite electrode under the high-temperature operation.

It has been widely proved that replacing low-capacity carbon anodes with the $\mathrm{Si}$ can tremendously improve the energy-storage capacity of LIBs. Unfortunately, the practical utilization of Si anode remains hindered by several issues. The trickiest part is the drastic volume changes during lithiation/delithiation processes, rendering electrical disconnection and capacity dropping [131]. A desirable surface coating has thus been pursued to settle this knot. As reported by Güneş, silicon NWs have been successfully synthesized on a 3D porous graphene foam combining with an ALD $\mathrm{Al}_{2} \mathrm{O}_{3}$ film of $\sim 10 \mathrm{~nm}$ in thickness, as depicted in Figure 7a. Corresponding SEM and TEM images are shown in Figure $7 \mathrm{~b}-\mathrm{d}$. Taking this unique ALD-assisted $\mathrm{Si}$ composites as anode material in LIBs, it yields high gravimetric and areal capacities, as well as comparable cycle life. As provided in Figure 7e,f, after 20 charge/discharge cycles, $\mathrm{ALD} \mathrm{Al}_{2} \mathrm{O}_{3}$-coated $\mathrm{Si} \mathrm{NWs}$ composites shows $\sim 83 \%$ capacity retention while the uncoated sample retains only $\sim 76 \%$ of the first cycle. At the 50 th cycle, the discharge capacities were decreased to $\sim 1125$ and $\sim 875 \mathrm{mAh} \cdot \mathrm{g}^{-1}$ for the ALD-assisted and bare 
samples, respectively. An $\mathrm{ALD} \mathrm{Al}_{2} \mathrm{O}_{3}$ coating layer on Si NWs not only cuts down the byproducts from side reactions but also reinforces the mechanical stress during the electrochemical reaction [49].

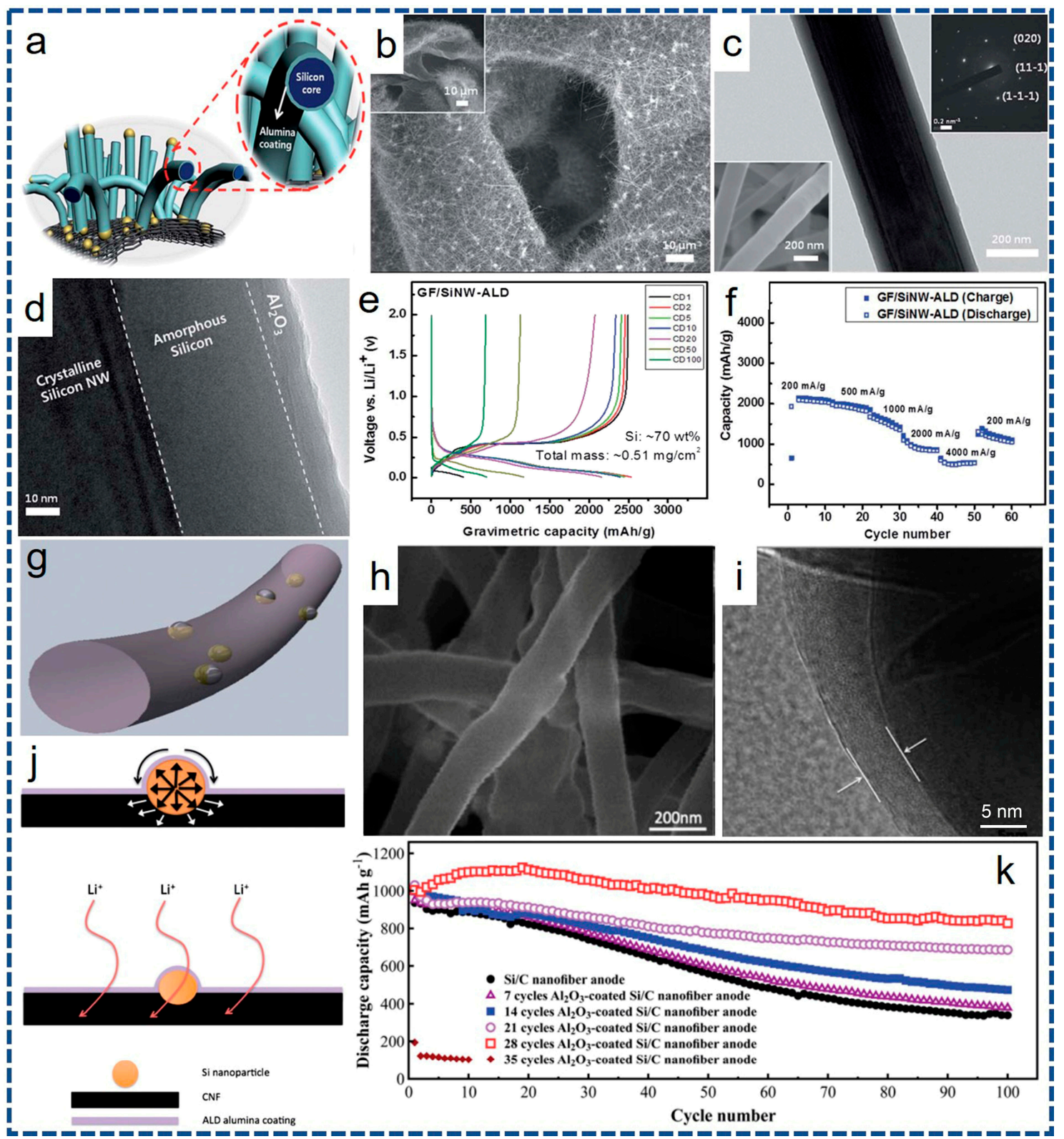

Figure 7. (a) Schematic illustration of $\mathrm{ALD} \mathrm{Al}_{2} \mathrm{O}_{3}$-coated $\mathrm{Si} \mathrm{NWs}$ grown on 3D porous graphene foam. (b) SEM images of Si NWs. (c) TEM and (d) High resolution transmission electron microscopy (HRTEM) images of a single $\mathrm{Al}_{2} \mathrm{O}_{3}$-coated Si NW. (e) Voltage profiles of for the 1st, 2nd, 5th, 10th, 20th and 50th cycles of $\mathrm{Al}_{2} \mathrm{O}_{3}$-coated Si NWs. (f) Rate capability of the $\mathrm{Al}_{2} \mathrm{O}_{3}$-coated Si NW composite with various currents as indicated. (g) Schematic of $\mathrm{Al}_{2} \mathrm{O}_{3}$-coated Si/C composite NFs. (h) SEM and (i) TEM image of $\mathrm{Al}_{2} \mathrm{O}_{3}$-coated $\mathrm{Si} / \mathrm{C}$ composite NFs with 28 ALD cycle numbers. (j) Schematic of physical/mechanical (upper) and chemical protective effect (down). (k) Cycling performance of $\mathrm{Si} / \mathrm{C}$ composite $\mathrm{NFs}$ and $\mathrm{Al}_{2} \mathrm{O}_{3}$-coated $\mathrm{Si} / \mathrm{C}$ composite NFs. (a-f) reprinted with permission from Ref. [129] @copyright 2016 Royal Society of Chemistry. (g-k) reprinted with permission from Ref. [132] @copyright 2014 Royal Society of Chemistry. 
Zhang and co-workers have thoroughly investigated the effects of $\mathrm{ALD}^{\mathrm{Al}} \mathrm{O}_{2} \mathrm{O}_{3}$ coatings with different thicknesses on electrochemical performance of Si/C composite nanofibers (NFs) [132]. As shown in Figure $7 \mathrm{~g}, \mathrm{Si} / \mathrm{C}$ composite NFs are obtained via electrospinning and following carbonization. The thickness of the subsequent $\mathrm{ALD} \mathrm{Al}_{2} \mathrm{O}_{3}$ coating layer is tuned at the monolayer-scale via adjusting the number of ALD cycles. Corresponding SEM and TEM images of $\mathrm{Al}_{2} \mathrm{O}_{3}$-coated $\mathrm{Si} / \mathrm{C}$ composite NFs with 28 ALD cycle numbers, as represented in Figure 7h,i, indicate that both the NFs and exposed Si nanoparticles are coated with bright shells corresponding to the $\mathrm{Al}_{2} \mathrm{O}_{3}$ coatings with a thickness of $\sim 5 \mathrm{~nm}$. This study powerfully proves that the $\mathrm{ALD} \mathrm{Al}_{2} \mathrm{O}_{3}$ coating can favor for maintaining the structure integrity and mitigating capacity fading, and further acts as an artificial SEI film to stabilize the electrode surface and to prevent undesirable side reactions during cycling, as vividly depicted in Figure 7j. The capacity retention at 100th cycle, as plotted in Figure 7k, increases significantly from 36.1 to $82.3 \%$ and corresponding CE increases from 98.4 to $99.9 \%$, compared to those of the uncoated Si/C NFs. Another positive case by $\mathrm{Lu}$ and co-workers [130] validates in detail that an $\mathrm{ALD} \mathrm{TiO}_{2}$ buffering layer $(\sim 3 \mathrm{~nm})$ remarkably affords the Si volume change inside the spheres during repeatedly alloying and de-alloying, which largely suppresses the pulverization and aggregation of $\mathrm{Si}$ particles. As a result, the core-shell $\mathrm{Si} @ \mathrm{TiO}_{2}$ anode material fabricated by ALD delivers a superior CE and charge capacity of $\sim 98 \%$ and $\sim 1580.3 \mathrm{mAh} \cdot \mathrm{g}^{-1}$ after 50 cycles. In addition, further studies [123-125] also confirm the cyclic stability of the Si anodes can be substantially enhanced after ALD surface coating.

The Li metal is regarded as the most attractive anode materials for LIBs, however, indisciplinable lithium dendrites growth leads to inferior cycling efficiency and severe safety issues, partially dragging the $\mathrm{Li}$ anode out of realistic applications [133]. In order to inhibit the detrimental reduction of electrolyte species on the Li metal surface, recently, Noked's group [127] prospectively develop a novel approach to stabilize Li metal surface by rationally employing unique ALD together with self-healing electrochemical polymerization (EP). Consequently, a hybrid organic/inorganic artificial solid electrolyte interphase (ASEI) including organic DOL and a thin inorganic ALD LiPON layer $(\sim 15 \mathrm{~nm})$, uniformly deposits upon the Li metal surface. Verification by electrochemical properties at increased current density and corresponding capacity is shown in Figure 8a. The corresponding blue rectangle from left to right stands for early cycle life, cycle life at $\mathrm{Li} / \mathrm{Li}$ cells showed unstable profiles (Li anode degraded), and cycle life at $\mathrm{Li} / \mathrm{Li}$ cells' failure, respectively. Apparently, early degeneration starts from only 55 cycles for bare Li cells, and the obvious failure occurs after 80 cycles. Nevertheless, the symmetric hybrid protected cells demonstrate stable cycling behavior up to over 110 cycles. Besides, SEM images for the surface changes of both electrodes ending on a Li plating cycle after 100 cycles, as represented in Figure $8 \mathrm{~b}-\mathrm{g}$, further validate the superiorities of the ALD in controllability and uniformly coating. Clearly, $\mathrm{Li}$ dendrites distribute randomly on the surface of the unprotected $\mathrm{Li}$, as a sharp contrast, the Li metal anode after ALD coating displays a stable, robust surface morphology, as distinctly depicted in Figure 8h,i. Accordingly, the coalition of an organic layer and an inorganic layer by the ALD is found to synergistically accommodate morphological and mechanical changes related to $\mathrm{Li}$ insertion/de-insertion. Equally, ultrathin $\mathrm{Al}_{2} \mathrm{O}_{3}$ protective layer $[134,135]$ and $\mathrm{Li}_{x} \mathrm{Al}_{y} S$ SSE [100] are of date employed to stabilize the electrode surface via the ALD. These in-depth investigations further demonstrate the unique advantages for sur-/interfacial modification via controllable and uniform ALD coating layer. Therefore, we have well-founded reasons to believe that the critical puzzles confronted by the Li metal anode can be considerably ameliorated via the advanced ALD technique. 


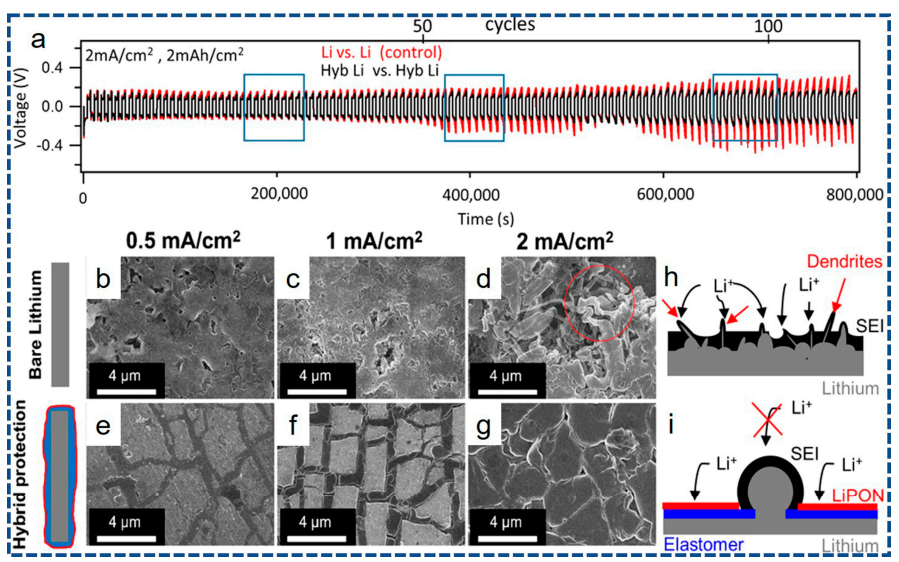

Figure 8. (a) Voltage profiles of bare $\mathrm{Li} / \mathrm{Li}$ (red) and hybrid protected $\mathrm{Li} / \mathrm{Li}$ at a high current density of $2 \mathrm{~mA} \cdot \mathrm{cm}^{-2}$ and a capacity of $2 \mathrm{mAh} \cdot \mathrm{cm}^{-2}$. (b-d) SEM images of bare Li metal and (e-g) hybrid-protected Li metal cycled for 100 cycles with varied current densities. Mechanistic schematics for (h) the bare Li and (i) hybrid elastomer/LiPON protection showing Li metal surface layer evolution after 100 cycles at current densities of $2 \mathrm{~mA} \cdot \mathrm{cm}^{-2}$. (a-i) reprinted with permission from Ref. [127] @copyright 2017 American Chemical Society.

Other conversional and intercalation metal oxides, sulfides, and Li-inserted compounds also obtain markedly improved structural and electrochemical properties, such as $\mathrm{SnS}_{2}$ [136,137], $\mathrm{SnO}_{2}$ [138], $\mathrm{MoO}_{3}$ [139], $\mathrm{Fe}_{3} \mathrm{O}_{4}$ [140], $\mathrm{Fe}_{2} \mathrm{O}_{3}$ [141], $\mathrm{CuO}$ [142] and $\mathrm{Li}_{4} \mathrm{Ti}_{5} \mathrm{O}_{12}$ [120]. As demonstrated by Alshareef et al., an optimal $\mathrm{HfO}_{2}$ layer $(\sim 1 \mathrm{~nm})$ corresponding to 10 ALD cycles effectively compromises between $\mathrm{Li}^{+}$ion diffusion and passivation effects. The exploration shows that $\mathrm{ALD} \mathrm{HfO} 2-\mathrm{Coated}_{\mathrm{MoO}}$ nanorods (NRs) tend to stabilize faster than the bare one due to the $\mathrm{HfO}_{2}$ coating layer [139]. Sun's group has studied and testified the accelerative function contributed by an ultrathin $\sim 2 \mathrm{~nm}$ ALD $\mathrm{ZrO}_{2}$ surface coating shell on the $\mathrm{Li}_{4} \mathrm{Ti}_{5} \mathrm{O}_{12}$ anode. Evidently, the $\mathrm{ZrO}_{2}$ coating layer can enormously suppress SEI formation and effectively facilitate the $\mathrm{Li}^{+}$ions diffusion through SEI film, and thus expand the potential window of $\mathrm{Li}_{4} \mathrm{Ti}_{5} \mathrm{O}_{12}$ anode for higher energy density [120].

Table 2. Summary of the ALD surface coatings on the anodes.

\begin{tabular}{|c|c|c|c|c|c|}
\hline Materials & $\begin{array}{l}\text { Coating } \\
\text { Materials }\end{array}$ & ALD Precursors & $\begin{array}{c}\text { ALD } \\
\text { Temperature }\end{array}$ & $\begin{array}{l}\text { Optimal Thickness, } \\
\text { ALD Cycles }\end{array}$ & Reference \\
\hline Carbon black & $\mathrm{Al}_{2} \mathrm{O}_{3}$ & TMA- $\mathrm{H}_{2} \mathrm{O}$ & $180^{\circ} \mathrm{C}$ & $\sim 2 \mathrm{~nm}, 20$ cycles & [143] \\
\hline Carbon nanofibers & $\mathrm{Al}_{2} \mathrm{O}_{3}$ & TMA- $\mathrm{H}_{2} \mathrm{O}$ & $150^{\circ} \mathrm{C}$ & 10 cycles & [144] \\
\hline Carbon & $\mathrm{TiO}_{2}$ & $\mathrm{TiCl}_{4}-\mathrm{H}_{2} \mathrm{O}$ & $120^{\circ} \mathrm{C}$ & $36.5 \mathrm{~nm}, 500$ cycles & [104] \\
\hline CNTs & $\mathrm{FePO}_{4} @ \mathrm{Li}_{3} \mathrm{PO}_{4}$ & $\begin{array}{l}\mathrm{C}_{10} \mathrm{H}_{10} \mathrm{Fe}+\mathrm{C}_{3} \mathrm{H}_{9} \mathrm{O}_{4} \mathrm{P}-\mathrm{H}_{2} \mathrm{O} \\
\mathrm{C}_{4} \mathrm{H}_{9} \mathrm{LiO}+\mathrm{C}_{3} \mathrm{H}_{9} \mathrm{O}_{4} \mathrm{P}-\mathrm{H}_{2} \mathrm{O}\end{array}$ & $\begin{array}{l}300^{\circ} \mathrm{C} \\
2500^{\circ} \mathrm{C}\end{array}$ & $12 \mathrm{~nm}, 400$ cycles & [145] \\
\hline CNTs & $\mathrm{SiO}_{2}$ & APTES + BDEAS- $\mathrm{H}_{2} \mathrm{O}$ & $150^{\circ} \mathrm{C}$ & $\sim 10 \mathrm{~nm}, 300$ cycles & [126] \\
\hline $\mathrm{Si}$ & $\mathrm{CNSs} @ \mathrm{Al}_{2} \mathrm{O}_{3}$ & TMA- $\mathrm{H}_{2} \mathrm{O}$ & $150^{\circ} \mathrm{C}$ & $\sim 6 \mathrm{~nm}, 50$ cycles & [124] \\
\hline $\mathrm{Si}$ & 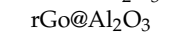 & TMA- $\mathrm{H}_{2} \mathrm{O}$ & $200^{\circ} \mathrm{C}$ & $\sim 2 \mathrm{~nm}, 20$ cycles & [125] \\
\hline Si-nanowires & $\mathrm{Al}_{2} \mathrm{O}_{3}$ & TMA- $\mathrm{H}_{2} \mathrm{O}$ & $200^{\circ} \mathrm{C}$ & $\sim 10 \mathrm{~nm}, 100$ cycles & [129] \\
\hline Amorphous Si & $\mathrm{Al}_{2} \mathrm{O}_{3}$ & TMA- $\mathrm{H}_{2} \mathrm{O}$ & $200^{\circ} \mathrm{C}$ & $\sim 3 \mathrm{~nm}$ & [123] \\
\hline $\mathrm{Si}$ & $\mathrm{Al}_{2} \mathrm{O}_{3}$ & TMA- $\mathrm{H}_{2} \mathrm{O}$ & $120^{\circ} \mathrm{C}$ & $\sim 5 \mathrm{~nm}, 28$ cycles & [132] \\
\hline $\mathrm{Si}$ & $\mathrm{TiO}_{2}$ & TTIP- $\mathrm{H}_{2} \mathrm{O}$ & $150^{\circ} \mathrm{C}$ & $\sim 3 \mathrm{~nm}$ & [130] \\
\hline Li metal & $\mathrm{Al}_{2} \mathrm{O}_{3}$ & TMA- $\mathrm{H}_{2} \mathrm{O}$ & $180^{\circ} \mathrm{C}$ & $\sim 2-3 \mathrm{~nm}, 30$ cycles & [135] \\
\hline Li metal & $\mathrm{Al}_{2} \mathrm{O}_{3}$ & TMA-plasma $\mathrm{O}_{2}$ & $100^{\circ} \mathrm{C}$ & $\sim 10.5 \mathrm{~nm}, 100$ cycles & [134] \\
\hline Li metal & $\mathrm{Li}_{x} \mathrm{Al}_{y} \mathrm{~S}$ & $\mathrm{Li}_{2} \mathrm{~S}-\mathrm{Al}_{2} \mathrm{~S}_{3}$ & $150^{\circ} \mathrm{C}$ & $\sim 50 \mathrm{~nm}$ & [100] \\
\hline Li metal & DOL@LiPON & $\mathrm{LiO}^{t} \mathrm{Bu} / \mathrm{TMP} / \mathrm{N}_{2}-\mathrm{H}_{2} \mathrm{O}$ & $150^{\circ} \mathrm{C}$ & $\sim 15 \mathrm{~nm}, 300$ cycles & [127] \\
\hline $\mathrm{Ge}$ & $\mathrm{TiO}_{2}$ & TTIP- $\mathrm{H}_{2} \mathrm{O}$ & $180^{\circ} \mathrm{C}$ & $\sim 5 \mathrm{~nm}$ & [102] \\
\hline $\mathrm{SnS}_{2}$ & $\mathrm{TiO}_{2}$ & TDMAT- $\mathrm{H}_{2} \mathrm{O}$ & $150^{\circ} \mathrm{C}$ & $\sim 4 \mathrm{~nm}, 80$ cycles & [136] \\
\hline $\mathrm{SnS}_{2}$ & $\mathrm{Al}_{2} \mathrm{O}_{3}$ & TMA- $\mathrm{H}_{2} \mathrm{O}$ & $120^{\circ} \mathrm{C}$ & $\sim 4.2 \mathrm{~nm}, 40$ cycles & [137] \\
\hline $\mathrm{SnO}_{2}$ & $\mathrm{GO} @ \mathrm{Al}_{2} \mathrm{O}_{3}$ & TMA- $\mathrm{H}_{2} \mathrm{O}$ & $200^{\circ} \mathrm{C}$ & $\sim 3 \mathrm{~nm}, 30$ cycles & [138] \\
\hline $\mathrm{MoO}_{3}$ & $\mathrm{HfO}_{2}$ & $\mathrm{Hf}\left(\mathrm{NMe}_{2}\right)_{4}-\mathrm{H}_{2} \mathrm{O}$ & $180^{\circ} \mathrm{C}$ & $\sim 3 \mathrm{~nm}, 10$ cycles & [139] \\
\hline $\mathrm{Fe}_{3} \mathrm{O}_{4}$ & $\mathrm{rGO} @ \mathrm{Al}_{2} \mathrm{O}_{3}$ & TMA- $\mathrm{H}_{2} \mathrm{O}$ & $80^{\circ} \mathrm{C}$ & $\sim 1 \mathrm{~nm}, 10$ cycles & [140] \\
\hline $\mathrm{Fe}_{2} \mathrm{O}_{3}$ & $\mathrm{TiO}_{2}$ & $\mathrm{FeC}_{10} \mathrm{H}_{10}-\mathrm{H}_{2} \mathrm{O}_{2}$ & $130^{\circ} \mathrm{C}$ & $\sim 10 \mathrm{~nm}$ & [141] \\
\hline $\mathrm{CuO}$ & $\mathrm{Al}_{2} \mathrm{O}_{3}$ & $\mathrm{Al}\left(\mathrm{CH}_{3}\right)_{3}-\mathrm{H}_{2} \mathrm{O}$ & $120^{\circ} \mathrm{C}$ & $\sim 10-15 \mathrm{~nm}$ & [142] \\
\hline $\mathrm{Si}-\mathrm{Cu}-\mathrm{Ti}$ & $\mathrm{Cu}_{3} \mathrm{Si}_{\mathrm{Al}_{2} \mathrm{O}_{3}}$ & TMA- $\mathrm{H}_{2} \mathrm{O}$ & $250^{\circ} \mathrm{C}$ & $\sim 2 \mathrm{~nm}, 20$ cycles & [146] \\
\hline
\end{tabular}

Trimethyl aluminum (TMA), (3-aminopropyl)triethoxysilane (APTES), bis-(diethylamino)silane (BDEAS), Hollow carbon nanospheres (CNSs), titanium isopropoxide (TTIP), 1,3-dioxolane (DOL); tetrakis(dimethyl-amido) titanium (TDMAT); graphene oxide (GO); reduced graphene oxide (rGO); Tetrakis (dimethylamino) hafnium $\left(\mathrm{Hf}\left(\mathrm{NMe}_{2}\right)_{4}\right)$. 
Table 3. Summary of ALD surface coatings on the cathodes.

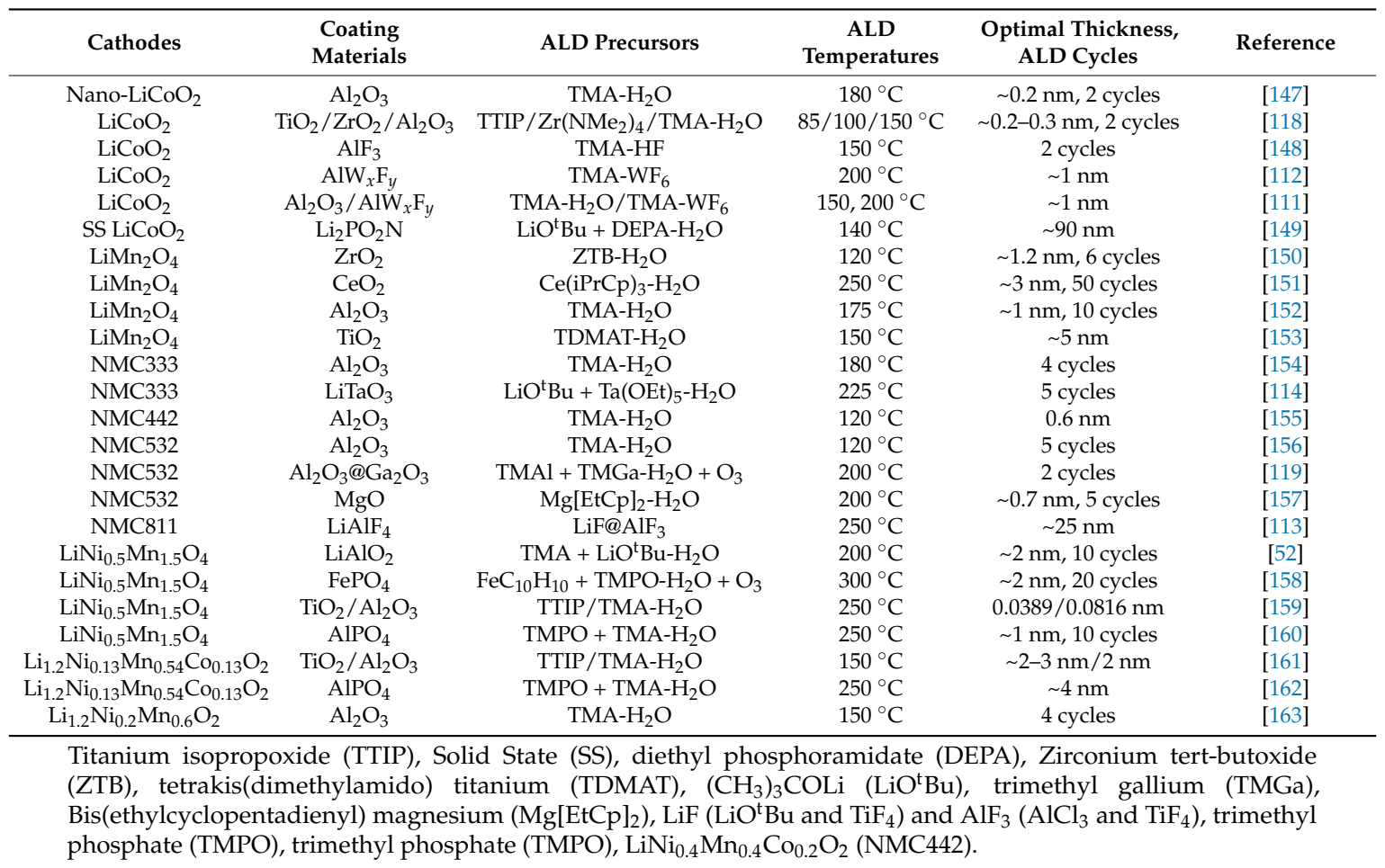

\subsection{Sur-/Interfacial Engineering in Cathodes via the ALD}

As extensively proved, the undesirable detrimental side-reactions are readily triggered off when the surface of cathode materials is directly exposed to the liquid electrolytes, including the electrolyte decomposition, irreversible phase degradation, and the oxygen loss and transition metals dissolution starting from the surface region $[10,164]$. Thus, rational surface coating depending on the surface characteristics of cathodes themselves has been widely implemented to restrict to the maximum the occurrence of side-reactions. Various compounds including metal oxides, phosphates and fluorides are utilized and studied for the surface coating. The coating layer can be functioned as a physical isolated film or HF scavenger, thus outstanding cyclic stability and rate capability are achieved. As for coating approaches, the ALD, in sharp comparison with the conventional mechanical mixing and sol-gel methods, affords extraordinary homogeneous cladding layer on the surface with precisely regulated down to sub-nanometers levels [5,164]. In this part, we comprehensively summarize the surface engineering via the ALD for cathode materials including layered cathodes, such as $\mathrm{LiCoO}_{2}[111,112,118,148,149], \mathrm{LiNi}_{x} \mathrm{Mn}_{y} \mathrm{Co}_{z} \mathrm{O}_{2}[113,114,119,154-157]$, and Li-rich $x \mathrm{Li}_{2} \mathrm{MnO}_{3} \cdot(1-x) \mathrm{LiMO}_{2}(\mathrm{M}=\mathrm{Mn}, \mathrm{Ni}, \mathrm{Co})$ [161-163], and spinel cathodes, such as $\mathrm{LiMn}_{2} \mathrm{O}_{4}$ [150-153] and $\mathrm{LiNi}_{0.5} \mathrm{Mn}_{1.5} \mathrm{O}_{4}$ [52,158-160], as listed in Table 3. After careful observation in Table 3, we can discover that the compounds serving as ALD coating layer for cathode materials can be mainly divided into four categories: metal oxides $\left(\mathrm{Al}_{2} \mathrm{O}_{3}[118,119,152,154-156,159,161,163,165,166]\right.$, $\mathrm{TiO}_{2}$ [118,153,159,161,166], $\mathrm{ZrO}_{2}$ [118,150], $\mathrm{MgO}$ [157], $\mathrm{CeO}_{2}$ [151], and $\mathrm{Ga}_{2} \mathrm{O}_{3}$ [119]), fluorides $\left(\mathrm{AlF}_{3}[148]\right.$ and $\left.\mathrm{AlW}_{x} \mathrm{~F}_{y}[111,112]\right)$, and phosphates $\left(\mathrm{AlPO}_{4}[160,162]\right.$ and $\left.\mathrm{FePO}_{4}[158]\right)$, and lithium containing compounds $\left(\mathrm{LiAlO}_{2}\right.$ [52], $\mathrm{LiTaO}_{3}[114]$ and $\mathrm{LiAlF}_{4}$ [113]). Subsequently, according to the different function mechanisms based on these four types of coating materials, the internal relationship between the textures of constructed ALD cathode materials and their superior electrochemical properties is elaborately reviewed here.

Similar to the studies of employing ALD to optimize anodes, metal oxides ALD coating (particularly $\mathrm{Al}_{2} \mathrm{O}_{3}$ ) are the first applied and most concerned for cathode material surface modification. Up to now, the $\mathrm{Al}_{2} \mathrm{O}_{3}$ coating has been widely utilized to stabilize the surface structure. Typically, 
as earlier investigation by Scott's group [147] show, electrochemical properties of the $\mathrm{LiCoO}_{2}$ are substantially enhanced with the $\mathrm{Al}_{2} \mathrm{O}_{3}$ coating layer deposited with a thickness of $\sim 1-2 \mathrm{~nm}$. The results show that the ALD $\mathrm{Al}_{2} \mathrm{O}_{3}$-coated electrodes have no capacity loss after 200 charge/discharge cycles at $2.8 \mathrm{C}$, in sharp contrast with the pristine one. In addition, the high-rate capability is also largely improved, which can be ascribed to the effective conservation of the electrode structure. Following this wave, other materials, such as $\mathrm{LiMn}_{2} \mathrm{O}_{4}, \mathrm{LiNi}_{0.5} \mathrm{Mn}_{1.5} \mathrm{O}_{4}$, and a series of Ni-based cathode including NMC333, NMC442 and NMC532, as well as Li-rich layered materials (such as $\left.\mathrm{Li}_{1.2} \mathrm{Ni}_{0.13} \mathrm{Mn}_{0.54} \mathrm{Co}_{0.13} \mathrm{O}_{2}\right)$ are well developed. Further convincing evidence for the positive role of the $\mathrm{Al}_{2} \mathrm{O}_{3}$ coating via the ALD on $\mathrm{LiNi}_{0.4} \mathrm{Mn}_{0.4} \mathrm{Co}_{0.2} \mathrm{O}_{2}$ has been recently probed by Ban and co-workers [155]. The $\mathrm{Al}_{2} \mathrm{O}_{3}$ layer mitigates the detrimental side reactions under high cut-off voltages $(>4.4 \mathrm{~V})$, without restricting the uptake and release of $\mathrm{Li}^{+}$ions, as conveyed in Figure 9a. This protective layer endows more highly active Ni oxide sites, thus promoting charge compensation via the oxidation of $\mathrm{Ni}$ and deserving high-rate capability, as shown in Figure 9b. Although the $\mathrm{ALD} \mathrm{Al}_{2} \mathrm{O}_{3}$ coating layer, acting as multifunctional roles in preserving the surface structural and chemical durability, the electronic conductivity of the working electrode will decline along with the increase in coating thickness [161,163]. Thus, the thickness of the coating layer should be precisely controlled via the ALD so as to guarantee the high electronic transportation. In consequence, other TMOs, representative of $\mathrm{TiO}_{2}$ and $\mathrm{ZrO}_{2}$, have been persistently pursued as coating layer by the ALD. Recently, the comparison of ultrathin $\mathrm{ALD} \mathrm{Al}_{2} \mathrm{O}_{3}$ and $\mathrm{TiO}_{2}$ integrating with spinel $\mathrm{LiMn}_{2} \mathrm{O}_{4}$ is detailed conducted by Mattelaer and co-workers [153]. Apparently, it can be observed from Figure 9c, d that an $\mathrm{Al}_{2} \mathrm{O}_{3}$ coating layer as thin as $0.5 \mathrm{~nm}$ already leads to a dramatic slow-down of the electrode kinetics. In addition, the $\mathrm{Al}_{2} \mathrm{O}_{3}$ of $\sim 1 \mathrm{~nm}$ in thickness cuts down the $200{ }^{\circ} \mathrm{C}$ capacity to half as compared to the uncoated $\mathrm{TiO}_{2}$ electrode, and with a $\sim 2 \mathrm{~nm} \mathrm{ALD} \mathrm{Al}_{2} \mathrm{O}_{3}$ only $7 \%$ retains. In stark contrast, the buried $\mathrm{TiO}_{2}$ even for the $\sim 5 \mathrm{~nm}$ coating still makes up more than $85 \%$ of the electrode. As reflected from the rate behaviors (Figure 9e), the rate capability is unaffected by the $\mathrm{TiO}_{2}$ coating since it does not pose an additional impedance on the electrode, while the $\mathrm{ALD} \mathrm{Al} \mathrm{O}_{3}$ coating is obviously detrimental due to the $1.5 \times 10^{12} \Omega \cdot \mathrm{cm}$ resistivity toward $\mathrm{Li}^{+}$ions. A significant study for the metal oxides ALD coating, Sun's group simultaneously studies and compares the specific influences of $\mathrm{ALD} \mathrm{Al} \mathrm{O}_{3}, \mathrm{TiO}_{2}$ and $\mathrm{ZrO}_{2}$ on $\mathrm{LiCoO}_{2}$ powders (I) vs. electrodes (II) and cycling and rate properties [118], as shown in Figure $9 \mathrm{f}$ and $g$, respectively. Apparently, electrochemical results fully confirm that the $\mathrm{Al}_{2} \mathrm{O}_{3}$ ALD coating affords the best cyclic stability while the $\mathrm{ZrO}_{2}$ ALD coating contributes to the best rate capability, resulting from the different intrinsic electronic conductivities of the two. This work also demonstrates that excessive ALD cycles will lead to inferior rate capability regardless of any metal oxide. Apart from the metal oxides mentioned above, other metal oxides such as $\mathrm{CeO}_{2}, \mathrm{MgO}$ and $\mathrm{Ga}_{2} \mathrm{O}_{3}$ are also successfully utilized via the ALD for surface modification of cathode materials. Interestingly, studies from Liang's group testify that a pin-hole free ALD layer of $\mathrm{CeO}_{2}$ modified on $\mathrm{LiMn}_{2} \mathrm{O}_{4}$ electrode can not only protect the electrode from harmful side reactions but also function as an electronic transportation path [151]. Therefore, we can ascertain that the metal oxide coating is a competitive technique to improve electrochemical properties of the cathodes, and the metal oxides should not be confined to the traditional metal oxides (e.g., $\mathrm{Al}_{2} \mathrm{O}_{3}$ ). Several critical factors including the coating thickness, electrical conductivity and electrical band structure, as well as the fracture toughness of the ALD metal oxides should be simultaneously taken into account [38,42]. 


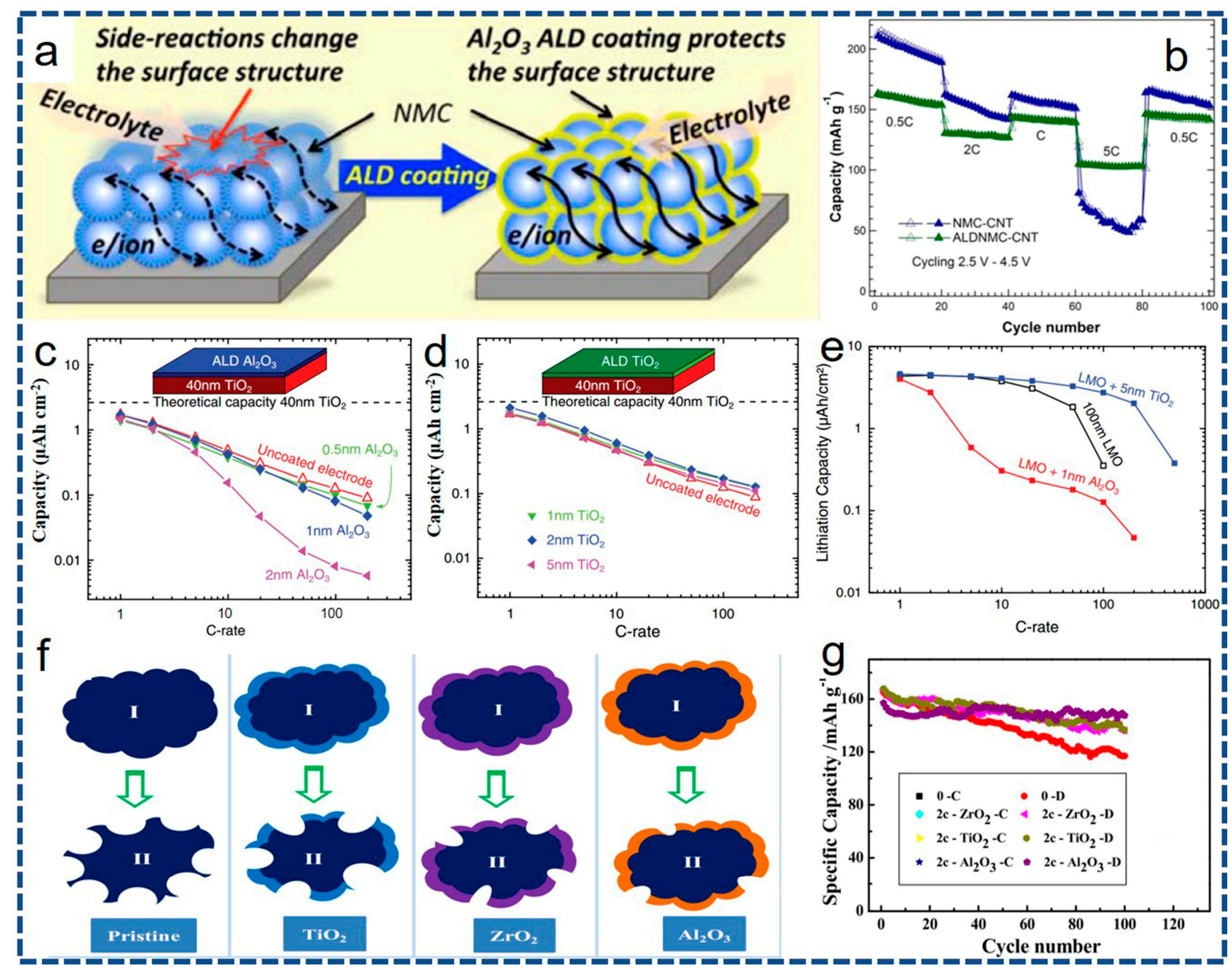

Figure 9. (a) Schematic illustration of comparison for bare and $\mathrm{Al}_{2} \mathrm{O}_{3}$-coated $\mathrm{NMC}$ electrodes. (b) High-voltage cycling performance of the bare and $\mathrm{Al}_{2} \mathrm{O}_{3}$-coated NMC electrodes cycled at 2.5-4.5 V (vs. $\mathrm{Li} / \mathrm{Li}^{+}$). (c,d) De-lithiation capacity of the electrodes measured by charging and discharging the films at current densities varying from 1 to $200{ }^{\circ} \mathrm{C}$ between 1.0 and $3.0 \mathrm{~V}$ (vs. $\mathrm{Li} / \mathrm{Li}^{+}$). (e) De-lithiation capacity of the bare and ALD-coated $\mathrm{LiMn}_{2} \mathrm{O}_{4}$ electrodes measured by charging and discharging the films at current densities at 3.5-4.5 V (vs. $\mathrm{Li}^{-} \mathrm{Li}^{+}$). (f) Schematic comparison of Co dissolution of $\mathrm{LiCoO}_{2}$ with various coating layers. (g) Comparison in cycling performance of $\mathrm{LiCoO}_{2}$ electrodes coated by different TMOs. (a,b) reprinted with permission from Ref. [155] @copyright 2015 American Chemical Society. (c-e) reprinted with permission from Ref. [153] @copyright 2017 Wiley. (f,g) reprinted with permission from Ref. [118] @copyright 2014 Elsevier.

Recently, Sun's group innovatively pioneered the ALD surface modification by using phosphates including $\mathrm{FePO}_{4}$ and $\mathrm{AlPO}_{4}$, which are directly deposited onto the initial powders rather than the whole electrode [158,160,162]. These phosphates with highly electronegativity of $\mathrm{PO}_{4}{ }^{3-}$ with $\mathrm{Al}^{3+} / \mathrm{Fe}^{3+}$ ions and amorphous structure do not trigger off any lattice stress, and consequently offer unhindered tunnels for $\mathrm{Li}^{+}$ions and considerable electronic conductivity. The HRTEM images displayed in Figure 10a reveal that the ultrathin $\mathrm{ALD} \mathrm{FePO}_{4}$ surface coating can be controlled to $\sim 2 \mathrm{~nm}$ in thickness. From electrochemical evaluation in Figure 10b, the ALD FePO 4 -coated samples evidently yield mounting capacity retention with increasing ALD cycles, which powerfully certifies the protective feature of the $\mathrm{ALD} \mathrm{FePO}_{4}$ shell. This can be put down to the significant suppression of Jahn-Teller distortion by $\mathrm{ALD} \mathrm{FePO}_{4}$ layer. Thus, the formation and dissolution of $\mathrm{Mn}^{2+}$ in the byproduct of $\mathrm{HF}$ decrease accordingly [158]. The equal study of great significance is that $\mathrm{AlPO}_{4}$ successfully serves as protective layer by the ALD, outstanding electrochemical properties are plotted in Figure 10c,d. The well-proportioned ultrathin $\mathrm{AlPO}_{4}$ layer not only functions as a protective layer to insulate 
active material and electrolyte, but also evolves into an artificial SEI layer upon cycling, substantially inhibiting the decomposition of electrolytes and integrating the surface structure [160]. Therefore, in comparison with the most widely studied of metal oxides, phosphates-based surface modification provides an alternative option, and has great opportunities to improve other energy storage systems according to this design.

An innovative promotion for ALD surface coating is to exploit some new and reasonable coating materials with desirable properties. Recently, in view of the insulating characteristics of metal oxides and relatively lower electrical conductivity of phosphates, lithium-containing compounds, as an ALD surface coating phase, has been investigated. For example, the possibility of building ultrathin ion-conducting $\mathrm{LiAlO}_{2}$ layers on $\mathrm{LiNi}_{0.5} \mathrm{Mn}_{1.5} \mathrm{O}_{4}$ electrode was initially explored by Park and coworkers [52]. After comparison with conventional $\mathrm{ALD} \mathrm{Al}_{2} \mathrm{O}_{3}$ layers, the $\mathrm{LiAlO}_{2}-\mathrm{Coated}$ electrode exhibits much more improved cyclic stability and rate capability, resulting from the better ionic conductivity of $\mathrm{LiAlO}_{2}$ than that of the $\mathrm{Al}_{2} \mathrm{O}_{3}$. In another representative study, the $\mathrm{LiTaO}_{3} \mathrm{SSE}$, as a ALD coating material, with a high ionic conductivity of $2 \times 10^{-8} \mathrm{~s} \cdot \mathrm{cm}^{-1}$ at room temperature (RT) is represented by $\mathrm{Li}$ and co-authors [114]. As a result, the surface structure degradation is remarkably decreased even employing a high cut-off voltage 3.0-4.8 V and the ALD $\mathrm{LiTaO}_{3} \mathrm{coated}$ electrode displays extraordinary electrochemical properties even at a high temperature of $55^{\circ} \mathrm{C}$. Lately, in order to operate at a wide electrochemical window to maximize energy density of the NMC811, Cui's group [113] has been successfully developed a $\mathrm{LiAlF}_{4}$ solid thin film with robust stability and satisfactory ion conductivity as a coating layer via the ALD. Typical TEM characterization of 50 ALD cycles of $\mathrm{LiAlF}_{4}$-coated NMC811 electrode after cycling is shown in Figure 10e. Clearly, the sturdy $\mathrm{LiAlF}_{4}$ layer is still completely unscathed and uniformly distributed on the surface of NMC811 particles after cycling. As reflected in Figure 10f, the electrode with the $\mathrm{LiAlF}_{4}$ coating shell retains a capacity higher than $\sim 140 \mathrm{mAh} \cdot \mathrm{g}^{-1}$ after 300 cycles, while for the pristine one, the capacities decline sharply to $<140 \mathrm{mAh} \cdot \mathrm{g}^{-1}$ after 113 cycles. This can be reasonably attributed to the $\mathrm{Li}^{+}$-conductive fluoride-based interfacial layer fabricated by the ALD, which is thermodynamically stable within a wide electrochemical window. As a result, the stability of the high-performance NMC811 electrodes is greatly enhanced.

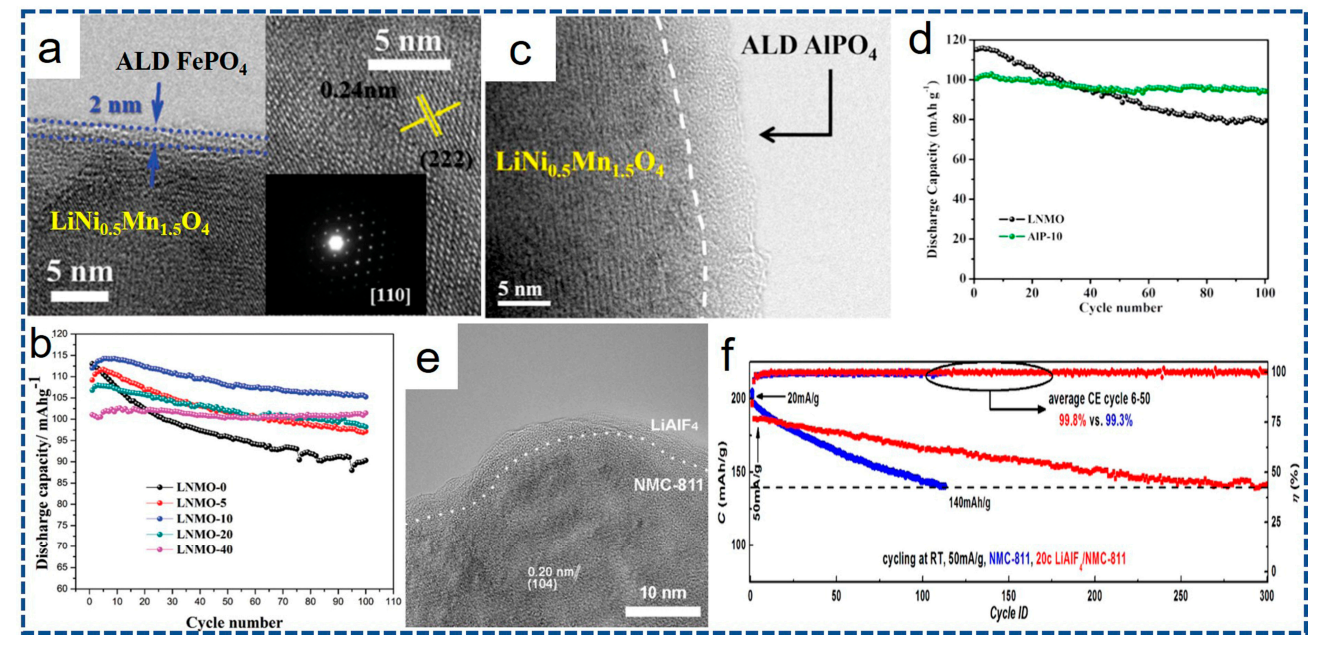

Figure 10. (a) HRTEM images and (b) cyclic stability of the ALD FePO $\mathrm{A}_{4}$-coated $\mathrm{LiNi}_{0.5} \mathrm{Mn}_{1.5} \mathrm{O}_{4}$ cathode. (c) HRTEM image and (d) cycling stability of the $\mathrm{AlPO}_{4}$-coated $\mathrm{LiNi}_{0.5} \mathrm{Mn}_{1.5} \mathrm{O}_{4}$ cathode. (e) TEM image of the $\mathrm{LiAlF}_{4}$-coated NMC811 electrode after cycling. (f) Cycling behaviors of the pristine and $\mathrm{LiAlF}_{4}$-coated NMC811 electrodes at room temperature (RT) within an electrochemical window of 2.75-4.50 V (vs. Li/ $\mathrm{Li}^{+}$). (a,b) reprinted with permission from Ref. [158] @copyright 2015 Wiley. (c,d) reprinted with permission from Ref. [160] @copyright 2017 Elsevier. (e,f) reprinted with permission from Ref. [113] @copyright 2017 American Chemical Society. 


\section{Concluding Remarks and Outlooks}

Nowadays, LIBs are the most widely applied and competitive energy-storage devices. However, they are still confronted with a series of critical issues, which definitely results from the deviant evolution process of electrode materials, regardless of cathodes or anodes. The pursuit of desirable electrode materials with remarkable physicochemical properties is ongoing. Over recent decades, the ALD, benefitting from its atomic accuracy and uniformity, has been rapidly advanced as a promising approach to construct high-performance electrode materials and SSEs for predesigned objectives, which are commonly difficult or even impossible to achieve by other common techniques. More significantly, the ALD also has been fully demonstrated to be a quite accurate and efficient method for electrode sur-/interface modifications. Hence, the ALD embodies several key advantages over conventional methodologies in coping with tough challenges associated with LIBs.

In this context, the up-to-date advances of the ALD in high-performance LIBs for designing and constructing prospective electrode materials and SSEs are comprehensively reviewed, with the aim to stimulate more extensive and in-depth investigations in improving electrochemical properties of LIBs via the advanced ALD nanotechnology. Even if tremendous achievements have been made with the ALD for rationally fabricating and/or optimizing electrode materials and inorganic SSE, a series of significant explorations need to be further attempted, and the underlying sur-/interfacial interaction mechanism should be clearly put forward.

One challenging direction is to further develop some new ALD coating materials, which largely depends on the successful exploration of several novel precursors. The promising materials as surface-coating phases on electrodes should simultaneously afford fresh sur-/interfacial chemistry, unimpeded $\mathrm{Li}^{+}$transportation and readily electrochemical reactions. As reviewed, Li-containing compounds, such as $\mathrm{LiTi}_{2}\left(\mathrm{PO}_{4}\right)_{3}$ and $\mathrm{Li}_{1.3} \mathrm{Al}_{0.3} \mathrm{Ti}_{1.7}\left(\mathrm{PO}_{4}\right)_{3}$ with high ionic conductivity $\left(\sim 10^{-3}-10^{-4} \mathrm{~S} \cdot \mathrm{cm}^{-1}\right)$, can be finely deposited with the existing precursors via the ALD for elegant surface modifications. Certainly, a considerable amount of other materials appropriate to ALD coating, such as metal oxides, fluorides, phosphates, and Li-containing compounds, should be persistently explored and optimized. It is especially worth mentioning that the surface modification of Ni-rich material (especially Ni content $\geq 0.6$ ) is imperative. Unfortunately, modifying Ni-rich cathodes via the ALD strategy has still not been paid enough attention to fundamentally address the haunting sur-/interfacial issues.

Another promising direction would be to purposefully design and fabricate novel electrode material by the ALD for enhanced electrochemical activities, which can not only accommodate larger capacities, but also contribute to in-depth comprehension in the basics. It is well recognized that nanoscaled dimensions play a significant role in optimally approaching theoretical expectations of electrodes themselves, especially for those with poor ion/electron conductivity. As an advanced nanotechnology, the ALD is particularly suitable for precise growth of various thin films with controllable atomic thickness on bulk substrates, such as Si wafers. Nevertheless, it is necessary to further leverage the emerging electrode materials with varying scales and/or dimensions by exploiting novel ALD process. For instance, it is of vital significance to fabricate a series of olivine $\mathrm{LiFe}_{x} \mathrm{Mn}_{y} \mathrm{PO}_{4}$ cathode materials via the ALD in 2D and 3D carbonaceous substrates, thus considerably improving its rate capability.

Besides, it is also greatly meaningful to deeply unravel the intrinsic interaction mechanism between the ALD coating phases and bulk materials. Thus, it would be clarified how these ALD coating materials can substantially mitigate the degeneration of electrode materials by comprehensively understanding structural evolution with and without the ALD coating. Consequently, the exploration of the ALD combining with cathodes and anodes can be rationally predicted, and further validly implemented. Towards this goal, sophisticated characterizations, particularly in situ techniques, should be developed, and provide more mechanistic insights.

Last but not least, with unique capability of the ALD to construct nanostructured films down to atomic scale, much more effort can be expected to build lithium-containing SSEs with high stability and 
exceptional ionic conductivity for all solid-state LIBs. More encouragingly, it is extremely interesting to construct an ideal heterostructure interface with low interfacial resistance via the ALD for inorganic SSEs application.

In summary, the advanced ALD nanotechnology has been extensively demonstrated to tremendously propel the speedy advancement of high-performance LIBs. One should particularly note that as for the newly emerging fields, the employment of the appealing ALD in next-generation LIBs, and even in rechargeable Na-ion batteries, metal-air batteries, fuel cells, and so on, deserves more intensive yet extensive promotion in the future.

Acknowledgments: This work was financially supported by the National Natural Science Foundation of China (Nos. 51772131; 51772127).

Author Contributions: Changzhou Yuan conceived and designed the frame of the whole paper; Xuan Sun, Xiaofei Sun, Chen Wu, Linrui Hou and Jinfeng Sun analyzed the data; Wei Lu and Longwei Liang wrote the paper.

Conflicts of Interest: The authors declare no conflict of interest.

\section{References}

1. Goodenough, J.B.; Park, K.S. The Li-Ion rechargeable battery: A perspective. J. Am. Chem. Soc. 2013, 135, 1167-1176. [CrossRef] [PubMed]

2. Manthiram, A. Materials challenges and opportunities of Lithium ion batteries. J. Phys. Chem. Lett. 2011, 2, 176-184. [CrossRef]

3. Manickam, M. Lithium-free transition metal phosphate cathode for Li secondary batteries. J. Power Sources 2003, 113, 179-183. [CrossRef]

4. Croguennec, L.; Palacin, M.R. Recent achievements on inorganic electrode materials for Lithium-ion batteries. J. Am. Chem. Soc. 2015, 137, 3140-3156. [CrossRef] [PubMed]

5. Kalluri, S.; Yoon, M.; Jo, M.; Liu, H.K.; Dou, S.X.; Cho, J.; Guo, Z. Feasibility of cathode surface coating technology for high-energy Lithium-ion and beyond-Lithium-ion batteries. Adv. Mater. 2017. [CrossRef] [PubMed]

6. Minakshi, M. Lithium intercalation into amorphous $\mathrm{FePO}_{4}$ cathode in aqueous solutions. Electrochim. Acta 2010, 55, 9174-9178. [CrossRef]

7. Palacin, M.R.; de Guibert, A. Why do batteries fail? Science 2016, 351, 1253292. [CrossRef] [PubMed]

8. Wu, L.; Nam, K.-W.; Wang, X.; Zhou, Y.; Zheng, J.-C.; Yang, X.-Q.; Zhu, Y. Structural origin of overcharge-induced thermal instability of Ni-containing layered-cathodes for high-energy-density Lithium batteries. Chem. Mater. 2011, 23, 3953-3960. [CrossRef]

9. Shim, J.-H.; Lee, S.; Park, S.S. Effects of $\mathrm{MgO}$ coating on the structural and electrochemical characteristics of $\mathrm{LiCoO}_{2}$ as cathode materials for Lithium ion battery. Chem. Mater. 2014, 26, 2537-2543. [CrossRef]

10. Kalluri, S.; Yoon, M.; Jo, M.; Park, S.; Myeong, S.; Kim, J.; Dou, S.X.; Guo, Z.; Cho, J. Surface engineering strategies of layered $\mathrm{LiCoO}_{2}$ cathode material to realize high-energy and high-voltage Li-ion cells. Adv. Energy Mater. 2017, 7, 1601507. [CrossRef]

11. Liang, L.W.; Jiang, F.; Cao, Y.B.; Hu, G.R.; Du, K.; Peng, Z.D. One strategy to enhance electrochemical properties of Ni-based cathode materials under high cut-off voltage for Li-ion batteries. J. Power Sources 2016, 328, 422-432. [CrossRef]

12. Jung, S.-K.; Gwon, H.; Hong, J.; Park, K.-Y.; Seo, D.-H.; Kim, H.; Hyun, J.; Yang, W.; Kang, K. Understanding the degradation mechanisms of $\mathrm{LiNi}_{0.5} \mathrm{Co}_{0.2} \mathrm{Mn}_{0.3} \mathrm{O}_{2}$ cathode material in Lithium ion batteries. Adv. Energy Mater. 2014, 4, 1300787. [CrossRef]

13. Xu, J.; Lin, F.; Doeff, M.M.; Tong, W. A review of Ni-based layered oxides for rechargeable Li-ion batteries. J. Mater. Chem. A 2017, 5, 874-901. [CrossRef]

14. Xu, M.; Fei, L.; Zhang, W.; Li, T.; Lu, W.; Zhang, N.; Lai, Y.; Zhang, Z.; Fang, J.; Zhang, K.; et al. Tailoring anisotropic Li-Ion transport tunnels on orthogonally arranged Li-rich layered oxide nanoplates toward high-performance Li-ion batteries. Nano Lett. 2017, 17, 1670-1677. [CrossRef] [PubMed]

15. Liu, W.; Oh, P.; Liu, X.; Myeong, S.; Cho, W.; Cho, J. Countering voltage decay and capacity fading of Lithium-rich cathode material at $60^{\circ} \mathrm{C}$ by hybrid surface protection layers. Adv. Energy Mater. 2015, 5, 1500274. [CrossRef] 
16. Tanaka, M.; Kageyama, T.; Sone, H.; Yoshida, S.; Okamoto, D.; Watanabe, T. Synthesis of Lithium Metal oxide nanoparticles by induction thermal plasmas. Nanomaterials 2016, 6, 60. [CrossRef] [PubMed]

17. Lee, S.; Yoon, G.; Jeong, M.; Lee, M.J.; Kang, K.; Cho, J. Hierarchical surface atomic structure of a manganese-based spinel cathode for Lithium-ion batteries. Angew. Chem. Int. Ed. 2015, 54, 1153-1158. [CrossRef] [PubMed]

18. Yan, K.; Lu, Z.; Lee, H.-W.; Xiong, F.; Hsu, P.-C.; Li, Y.; Zhao, J.; Chu, S.; Cui, Y. Selective deposition and stable encapsulation of Lithium through heterogeneous seeded growth. Nat. Energy 2016, 1, 16010. [CrossRef]

19. Ji, G.; Ma, Y.; Ding, B.; Lee, J.Y. Improving the performance of high capacity Li-ion anode materials by Lithium Titanate surface coating. Chem. Mater. 2012, 24, 3329-3334. [CrossRef]

20. Qin, M.; Li, Y.; Lv, X.J. Preparation of Ce- and La-doped $\mathrm{Li}_{4} \mathrm{Ti}_{5} \mathrm{O}_{12}$ nanosheets and their electrochemical performance in $\mathrm{Li}$ half cell and $\mathrm{Li}_{4} \mathrm{Ti}_{5} \mathrm{O}_{12} / \mathrm{LiFePO}_{4}$ full cell batteries. Nanomaterials 2017, 7, 150. [CrossRef] [PubMed]

21. Su, X.; Wu, Q.; Li, J.; Xiao, X.; Lott, A.; Lu, W.; Sheldon, B.W.; Wu, J. Silicon-based nanomaterials for Lithium-ion batteries: A review. Adv. Energy Mater. 2014, 4, 1300882. [CrossRef]

22. Ma, D.; Shi, X.; Hu, A. A facile method to in situ synthesize porous $\mathrm{Ni}_{2} \mathrm{GeO}_{4}$ nano-sheets on Nickel foam as advanced anode electrodes for Li-ion batteries. Nanomaterials (Basel) 2016, 6, 218. [CrossRef] [PubMed]

23. Kubo, S.; White, R.J.; Tauer, K.; Titirici, M.-M. Flexible coral-like Carbon nanoarchitectures via a dual block copolymer-Latex templating approach. Chem. Mater. 2013, 25, 4781-4790. [CrossRef]

24. Mauger, A.; Julien, C.M. Nanoscience supporting the research on the negative electrodes of Li-ion batteries. Nanomaterials 2015, 5, 2279-2301. [CrossRef] [PubMed]

25. Lin, F.; Nordlund, D.; Li, Y.; Quan, M.K.; Cheng, L.; Weng, T.-C.; Liu, Y.; Xin, H.L.; Doeff, M.M. Metal segregation in hierarchically structured cathode materials for high-energy Lithium batteries. Nat. Energy 2016, 1, 15004. [CrossRef]

26. Noh, H.J.; Ju, J.W.; Sun, Y.K. Comparison of nanorod-structured $\mathrm{Li}\left[\mathrm{Ni}_{0.54} \mathrm{Co}_{0.16} \mathrm{Mn}_{0.30}\right]_{2}$ with conventional cathode materials for Li-ion batteries. ChemSusChem 2014, 7, 245-252. [CrossRef] [PubMed]

27. Penki, T.R.; Shivakumara, S.; Minakshi, M.; Munichandraiah, N. Porous flower-like $\alpha-\mathrm{Fe}_{2} \mathrm{O}_{3}$ nanostructure: A high performance anode material for Lithium-ion batteries. Electrochim. Acta 2015, 167, 330-339. [CrossRef]

28. Ji, L.W.; Lin, Z.; Alcoutlabi, M.; Zhang, X.W. Recent developments in nanostructured anode materials for rechargeable Lithium-ion batteries. Energy Environ. Sci. 2011, 4, 2682-2699. [CrossRef]

29. Lu, J.; Peng, Q.; Wang, W.; Nan, C.; Li, L.; Li, Y. Nanoscale coating of $\mathrm{LiMO}_{2}(\mathrm{M}=\mathrm{Ni}, \mathrm{Co}, \mathrm{Mn})$ nanobelts with $\mathrm{Li}^{+}$-conductive $\mathrm{L}_{\mathrm{i} 2} \mathrm{TiO}_{3}$ : Toward better rate capabilities for $\mathrm{Li}$-ion batteries. J. Am. Chem. Soc. 2013, 135, 1649-1652. [CrossRef] [PubMed]

30. Wu, F.; Li, N.; Su, Y.; Shou, H.; Bao, L.; Yang, W.; Zhang, L.; An, R.; Chen, S. Spinel/Layered heterostructured cathode material for high-capacity and high-rate Li-ion batteries. Adv. Mater. 2013, 25, 3722-3726. [CrossRef] [PubMed]

31. Deng, Y.-F.; Zhao, S.-X.; Xu, Y.-H.; Nan, C.-W. Effect of temperature of $\mathrm{Li}_{2} \mathrm{O}-\mathrm{Al}_{2} \mathrm{O}_{3}-\mathrm{TiO}_{2}-\mathrm{P}_{2} \mathrm{O}_{5}$ solid-state electrolyte coating process on the performance of $\mathrm{LiNi}_{0.5} \mathrm{Mn}_{1.5} \mathrm{O}_{4}$ cathode materials. J. Power Sources 2015, 296, 261-267. [CrossRef]

32. Liang, L.; Wu, C.; Sun, X.; Sun, X.; Hou, L.; Sun, J.; Yuan, C. Sur-/Interface engineering of hierarchical $\mathrm{LiNi}_{0.6} \mathrm{Mn}_{0.2} \mathrm{Co}_{0.2} \mathrm{O}_{2} @ \mathrm{LiCoPO}_{4} @ G r a p h e n e$ architectures as promising high-voltage cathodes toward advanced Li-ion batteries. Adv. Mater. Interfaces 2017, 4, 1700382. [CrossRef]

33. Wu, Z.; Ji, S.; Liu, T.; Duan, Y.; Xiao, S.; Lin, Y.; Xu, K.; Pan, F. Aligned $\mathrm{Li}^{+}$tunnels in core-shell $\mathrm{Li}\left(\mathrm{Ni}_{x} \mathrm{Mn}_{y} \mathrm{Co}_{z}\right) \mathrm{O}_{2} @ \mathrm{LiFePO}_{4}$ enhances its high voltage cycling stability as Li-ion battery cathode. Nano Lett. 2016, 16, 6357-6363. [CrossRef] [PubMed]

34. Wang, J.; Yu, Y.; Li, B.; Zhang, P.; Huang, J.; Wang, F.; Zhao, S.; Gan, C.; Zhao, J. Thermal synergy effect between $\mathrm{LiNi}_{0.5} \mathrm{Co}_{0.2} \mathrm{Mn}_{0.3} \mathrm{O}_{2}$ and $\mathrm{LiMn}_{2} \mathrm{O}_{4}$ enhances the safety of blended cathode for Lithium ion batteries. ACS Appl. Mater. Interfaces 2016, 8, 20147-20156. [CrossRef] [PubMed]

35. Deng, J.C.; Xu, Y.L.; Li, L.; Feng, T.Y.; Li, L. Microporous $\mathrm{LiAlSiO}_{4}$ with high ionic conductivity working as a coating material and water adsorbent for $\mathrm{LiNi}_{0.5} \mathrm{Mn}_{1.5} \mathrm{O}_{4}$ Cathode. J. Mater. Chem. A 2016, 4, 6561-6568. [CrossRef]

36. Liang, L.; Jiang, J.; Jiang, F.; Hu, G.; Cao, Y.; Peng, Z.; Du, K. An ordered olivine-type $\mathrm{LiCoPO}_{4}$ layer grown on $\mathrm{LiNi}_{0.6} \mathrm{Mn}_{0.2} \mathrm{Co}_{0.2} \mathrm{O}_{2}$ cathode materials applied to Lithium-ion batteries. J. Alloys Compd. 2017, 695, 1993-1997. [CrossRef] 
37. Kim, H.; Kim, M.G.; Jeong, H.Y.; Nam, H.; Cho, J. A new coating method for alleviating surface degradation of $\mathrm{LiNi}_{0.6} \mathrm{Co}_{0.2} \mathrm{Mn}_{0.2} \mathrm{O}_{2}$ cathode material: Nanoscale surface treatment of primary particles. Nano Lett. 2015, 15, 2111-2119. [CrossRef] [PubMed]

38. Ma, L.; Nuwayhid, R.B.; Wu, T.; Lei, Y.; Amine, K.; Lu, J. Atomic layer deposition for Lithium-based batteries. Adv. Mater. Interfaces 2016, 3, 1600564. [CrossRef]

39. Johnson, R.W.; Hultqvist, A.; Bent, S.F. A brief review of atomic layer deposition: From fundamentals to applications. Mater. Today 2014, 17, 236-246. [CrossRef]

40. Liu, J.; Sun, X. Elegant design of electrode and electrode/electrolyte interface in Lithium-ion batteries by atomic layer deposition. Nanotechnology 2015, 26, 024001. [CrossRef] [PubMed]

41. Meng, X.; Yang, X.Q.; Sun, X. Emerging applications of atomic layer deposition for Lithium-ion battery studies. Adv. Mater. 2012, 24, 3589-3615. [CrossRef] [PubMed]

42. Wen, L.; Zhou, M.; Wang, C.; Mi, Y.; Lei, Y. Nanoengineering energy conversion and storage devices via atomic layer deposition. Adv. Energy Mater. 2016, 6, 1600468. [CrossRef]

43. Yan, B.; Li, X.; Bai, Z.; Song, X.; Xiong, D.; Zhao, M.; Li, D.; Lu, S. A review of atomic layer deposition providing high performance Lithium sulfur batteries. J. Power Sources 2017, 338, 34-48. [CrossRef]

44. Leskela, M.; Ritala, M. Atomic layer deposition chemistry: Recent developments and future challenges. Angew. Chem. Int. Ed. Engl. 2003, 42, 5548-5554. [CrossRef] [PubMed]

45. Wang, X.; Yushin, G. Chemical vapor deposition and atomic layer deposition for advanced Lithium ion batteries and supercapacitors. Energy Environ. Sci. 2015, 8, 1889-1904. [CrossRef]

46. Aravindan, V.; Jinesh, K.B.; Prabhakar, R.R.; Kale, V.S.; Madhavi, S. Atomic layer deposited (ALD) $\mathrm{SnO}_{2}$ anodes with exceptional cycleability for Li-ion batteries. Nano Energy 2013, 2, 720-725. [CrossRef]

47. Sreedhara, M.B.; Ghatak, J.; Bharath, B.; Rao, C.N. Atomic layer deposition of ultrathin crystalline epitaxial films of $\mathrm{V}_{2} \mathrm{O}_{5}$. ACS Appl. Mater. Interfaces 2017, 9, 3178-3185. [CrossRef] [PubMed]

48. Liu, J.; Banis, M.N.; Sun, Q.; Lushington, A.; Li, R.; Sham, T.K.; Sun, X. Rational design of atomic-layer-deposited $\mathrm{LiFePO}_{4}$ as a high-performance cathode for Lithium-ion batteries. Adv. Mater. 2014, 26, 6472-6477. [CrossRef] [PubMed]

49. Guan, C.; Wang, J. Recent development of advanced electrode materials by atomic layer deposition for electrochemical energy storage. Adv. Sci. 2016, 3, 1500405. [CrossRef] [PubMed]

50. Ahmed, B.; Xia, C.; Alshareef, H.N. Electrode surface engineering by atomic layer deposition: A promising pathway toward better energy storage. Nano Today 2016, 11, 250-271. [CrossRef]

51. Gao, Z.; Qin, Y. Design and properties of confined nanocatalysts by atomic layer deposition. Acc. Chem. Res. 2017, 50, 2309-2316. [CrossRef] [PubMed]

52. Park, J.S.; Meng, X.; Elam, J.W.; Hao, S.; Wolverton, C.; Kim, C.; Cabana, J. Ultrathin Lithium-ion conducting coatings for increased interfacial stability in high voltage Lithium-ion batteries. Chem. Mater. 2014, 26, 3128-3134. [CrossRef]

53. George, S.M. Atomic layer deposition: An overview. Chem. Rev. 2010, 110, 111-131. [CrossRef] [PubMed]

54. Zaera, F. The surface chemistry of atomic layer depositions of solid thin films. J. Phys. Chem. Lett. 2012, 3, 1301-1309. [CrossRef] [PubMed]

55. Miikkulainen, V.; Leskelä, M.; Ritala, M.; Puurunen, R.L. Crystallinity of inorganic films grown by atomic layer deposition: Overview and general trends. J. Appl. Phys. 2013, 113, 021301. [CrossRef]

56. Gregorczyk, K.; Knez, M. Hybrid nanomaterials through molecular and atomic layer deposition: Top down, bottom up, and in-between approaches to new materials. Prog. Mater. Sci. 2016, 75, 1-37. [CrossRef]

57. Kozen, A.C.; Lin, C.-F.; Pearse, A.J.; Schroeder, M.A.; Han, X.G.; Hu, L.B.; Lee, S.-B.; Rubloff, G.W.; Noked, M. Next-generation Lithium metal anode engineering via atomic layer deposition. ACS Nano 2015, 6, 5881-5892.

58. Meng, X.B.; Comstock, D.J.; Fister, T.T.; Elam, J.W. Vapor-Phase atomic-controllable growth of amorphous $\mathrm{Li}_{2} \mathrm{~S}$ for highperformance Lithium-sulfur batteries. ACS Nano 2014, 10, 10963-10972. [CrossRef] [PubMed]

59. Zhao, Y.; Goncharova, L.V.; Lushington, A.; Sun, Q.; Yadegari, H.; Wang, B.Q.; Xiao, W.; Li, R.Y.; Sun, X.L. Superior stable and long life sodium metal anodes achieved by atomic layer deposition. Adv. Mater. 2017, 29, 1606663. [CrossRef] [PubMed]

60. Alvarado, J.; Ma, C.Z.; Wang, S.; Nguyen, K.; Kodur, M.; Meng, Y.S. Improvement of the cathode electrolyte interphase on $\mathrm{P}_{2}-\mathrm{Na}_{2 / 3} \mathrm{Ni}_{1 / 3} \mathrm{Mn}_{2 / 3} \mathrm{O}_{2}$ by atomic layer deposition. ACS Appl. Mater. Interfaces 2017, 9, 26518-26530. [CrossRef] [PubMed] 
61. Meng, X.B. Atomic-scale surface modifications and novel electrode designs for high-performance sodium-ion batteries via atomic layer deposition. J. Mater. Chem. A 2017, 5, 10127-10149. [CrossRef]

62. Zhong, L.; Mitchell, R.R.; Liu, Y.; Gallant, B.M.; Thompson, C.V.; Huang, J.Y.; Mao, S.X.; Yang, S.-H. In Situ transmission electron microscopy observations of electrochemical oxidation of $\mathrm{Li}_{2} \mathrm{O}_{2}$. Nano Lett. 2013, 13, 2209-2214. [CrossRef] [PubMed]

63. Daubert, J.S.; Lewis, N.P.; Gotsch, H.N.; Mundy, J.Z.; Monroe, D.N.; Dickey, E.C.; Losego, M.D.; Parsons, G.N. Effect of Meso- and micro-porosity in carbon electrodes on atomic layer deposition of pseudocapacitive $\mathrm{V}_{2} \mathrm{O}_{5}$ for high performance supercapacitors. Chem. Mater. 2015, 27, 6524-6534. [CrossRef]

64. Guan, C.; Liu, J.L.; Wang, Y.D.; Mao, L.; Fan, Z.X.; Shen, Z.X.; Zhang, H.; Wang, J. Iron oxide-decorated carbon for supercapacitor anodes with ultrahigh energy density and outstanding cycling stability. ACS Nano 2015, 5, 5198-5207. [CrossRef] [PubMed]

65. Huang, H.B.; Lv, J.; Bao, Y.M.; Xuan, R.W.; Sun, S.H.; Sneck, S.; Li, S.; Modanese, C.; Savin, H.; Wang, A.H.; et al. 20.8\% Industrial PERC solar cell: $\mathrm{ALD} \mathrm{Al}_{2} \mathrm{O}_{3}$ rear surface passivation, efficiency loss mechanisms analysis and roadmap to 24\%. Sol. Energy Mater. Sol. Cell 2017, 161, 14-30. [CrossRef]

66. Kim, H.G.; Lee, H.-B.-R. Atomic layer deposition on 2D materials. Chem. Mater. 2017, 29, 3809-3826. [CrossRef]

67. Lin, C.F.; Noked, M.; Kozen, A.C.; Liu, C.; Zhao, O.; Gregorczyk, K.; Hu, L.; Lee, S.B.; Rubloff, G.W. Solid electrolyte Lithium phosphous oxynitride as a protective nanocladding layer for 3D high-capacity conversion electrodes. ACS Nano 2016, 10, 2693-2701. [CrossRef] [PubMed]

68. Haag, J.M.; Pattanaik, G.; Durstock, M.F. Nanostructured 3D electrode architectures for high-rate Li-Ion batteries. Adv. Mater. 2013, 25, 3238-3243. [CrossRef] [PubMed]

69. Xie, M.; Sun, X.; George, S.M.; Zhou, C.; Lian, J.; Zhou, Y. Amorphous ultrathin $\mathrm{SnO}_{2}$ films by atomic layer deposition on graphene network as highly stable anodes for Lithium-ion batteries. ACS Appl. Mater. Interfaces 2015, 7, 27735-27742. [CrossRef] [PubMed]

70. Ahmed, B.; Anjum, D.H.; Gogotsi, Y.; Alshareef, H.N. Atomic layer deposition of $\mathrm{SnO}_{2}$ on MXene for Li-ion battery anodes. Nano Energy 2017, 34, 249-256. [CrossRef]

71. Kim, W.-S.; Lee, B.-S.; Kim, D.-H.; Kim, H.-C.; Yu, W.-R.; Hong, S.-H. $\mathrm{SnO}_{2}$ nanotubes fabricated using electrospinning and atomic layer deposition and their gas sensing performance. Nanotechnology 2010, 21, 245605. [CrossRef] [PubMed]

72. Guan, C.; Li, X.; Yu, H.; Mao, L.; Wong, L.H.; Yan, Q.; Wang, J. A novel hollowed CoO-in-CoSnO 3 nanostructure with enhanced Lithium storage capabilities. Nanoscale 2014, 6, 13824-13830. [CrossRef] [PubMed]

73. Kim, M.; Lee, J.; Lee, S.; Seo, S.; Bae, C.; Shin, H. Nanotubular heterostructure of Tin Dioxide/Titanium dioxide as a binder-free anode in Lithium-ion batteries. ChemSusChem 2015, 8, 2363-2371. [CrossRef] [PubMed]

74. Zhang, H.; Ren, W.; Cheng, C. Three-dimensional $\mathrm{SnO}_{2} @ \mathrm{TiO}_{2}$ double-shell nanotubes on carbon cloth as a flexible anode for Lithium-ion batteries. Nanotechnology 2015, 26, 274002. [CrossRef] [PubMed]

75. Wang, H.; Jia, G.; Guo, Y.; Zhang, Y.; Geng, H.; Xu, J.; Mai, W.; Yan, Q.; Fan, H.J. Atomic layer deposition of amorphous $\mathrm{TiO}_{2}$ on carbon nanotube networks and their superior $\mathrm{Li}$ and $\mathrm{Na}$ ion storage properties. Adv. Mate. Interfaces 2016, 3, 1600375. [CrossRef]

76. Li, M.; Li, X.; Li, W.; Meng, X.; Yu, Y.; Sun, X. Atomic layer deposition derived amorphous $\mathrm{TiO}_{2}$ thin film decorating graphene nanosheets with superior rate capability. Electrochem. Commun. 2015, 57, 43-47. [CrossRef]

77. Charlton, M.R.; Dylla, A.G.; Stevenson, K.J. Direct evidence of a chemical conversion mechanism of atomic-layer-deposited $\mathrm{TiO}_{2}$ anodes during Lithiation using $\mathrm{LiPF}_{6}$ salt. J. Phys. Chem. C 2015, 119, 28285-28291. [CrossRef]

78. Hong, K.J.; Kim, S.O. Atomic layer deposition assisted sacrificial template synthesis of mesoporous $\mathrm{TiO}_{2}$ electrode for high performance Lithium ion battery anodes. Energy Storage Mater. 2016, 2, 27-34. [CrossRef]

79. Xie, M.; Sun, X.; Zhou, C.; Cavanagh, A.S.; Sun, H.; Hu, T.; Wang, G.; Lian, J.; George, S.M. Amorphous ultrathin $\mathrm{TiO}_{2}$ atomic layer deposition films on carbon nanotubes as anodes for Lithium ion batteries. J. Electrochem. Soc. 2015, 162, A974-A981. [CrossRef] 
80. Ye, J.C.; Baumgaertel, A.C.; Wang, Y.M.; Biene, J.; Biener, M.M. Structural optimization of 3D porous electrodes for high-rate performance Lithium ion batteries. ACS Nano 2015, 9, 2194-2202. [CrossRef] [PubMed]

81. Lu, S.; Wang, H.; Zhou, J.; Wu, X.; Qin, W. Atomic layer deposition of ZnO on carbon black as nanostructured anode materials for high-performance Lithium-ion batteries. Nanoscale 2017, 9, 1184-1192. [CrossRef] [PubMed]

82. Wang, G.; Lu, C.; Zhang, X.; Wan, B.; Liu, H.; Xia, M.; Gou, H.; Xin, G.; Lian, J.; Zhang, Y. Toward ultrafast Lithium ion capacitors: A novel atomic layer deposition seeded preparation of $\mathrm{Li}_{4} \mathrm{Ti}_{5} \mathrm{O}_{12}$ /Graphene anode. Nano Energy 2017, 36, 46-57. [CrossRef]

83. Nandi, D.K.; Sen, U.K.; Dhara, A.; Mitra, S.; Sarkar, S.K. Intercalation based Tungsten Disulfide $\left(\mathrm{WS}_{2}\right) \mathrm{Li}_{\text {-ion }}$ battery anode grown by atomic layer deposition. RSC. Adv. 2016, 6, 38024-38032. [CrossRef]

84. Nandi, D.K.; Sen, U.K.; Choudhury, D.; Mitra, S.; Sarkar, S.K. Atomic layer deposited molybdenum nitride thin film: A promising anode material for Li ion batteries. ACS Appl. Mater. Interfaces 2014, 6, 6606-6615. [CrossRef] [PubMed]

85. Nandi, D.K.; Sen, U.K.; Sinha, S.; Dhara, A.; Mitra, S.; Sarkar, S.K. Atomic layer deposited tungsten nitride thin films as a new Lithium-ion battery anode. Phys. Chem. Chem. Phys. 2015, 17, 17445-17453. [CrossRef] [PubMed]

86. Nisula, M.; Karppinen, M. Atomic/Molecular layer deposition of Lithium terephthalate thin films as high rate capability Li-ion battery anodes. Nano Lett. 2016, 16, 1276-1281. [CrossRef] [PubMed]

87. Chen, X.; Pomerantseva, E.; Banerjee, P.; Gregorczyk, K.; Ghodssi, R.; Rubloff, G. Ozone-based atomic layer deposition of crystalline $\mathrm{V}_{2} \mathrm{O}_{5}$ films for high performance electrochemical energy storage. Chem. Mater. 2012, 24, 1255-1261. [CrossRef]

88. Chen, X.Y.; Zhu, H.L.; Chen, Y.C.; Shang, Y.Y.; Cao, A.Y.; Hu, L.B.; Rubloff, G.W. MWCNT/ $\mathrm{V}_{2} \mathrm{O}_{5}$ core/shell sponge for high areal capacity and power density Li-ion cathodes. ACS Nano 2012, 9, 7948-7955. [CrossRef] [PubMed]

89. Østreng, E.; Gandrud, K.B.; Hu, Y.; Nilsen, O.; Fjellvåg, H. High power nano-structured $\mathrm{V}_{2} \mathrm{O}_{5}$ thin film cathodes by atomic layer deposition. J. Mater. Chem. A 2014, 2, 15044-15051. [CrossRef]

90. Xie, M.; Sun, X.; Sun, H.; Porcelli, T.; George, S.M.; Zhou, Y.; Lian, J. Stabilizing an amorphous $\mathrm{V}_{2} \mathrm{O}_{5} /$ Carbon nanotube paper electrode with conformal $\mathrm{TiO}_{2}$ coating by atomic layer deposition for Lithium ion batteries. J. Mater. Chem. A 2016, 4, 537-544. [CrossRef]

91. Liu, J.; Xiao, B.; Banis, M.N.; Li, R.; Sham, T.-K.; Sun, X. Atomic layer deposition of amorphous iron phosphates on carbon nanotubes as cathode materials for Lithium-ion batteries. Electrochim. Acta 2015, 162, 275-281. [CrossRef]

92. Donders, M.E.; Arnoldbik, W.M.; Knoops, H.C.M.; Kessels, W.M.M.; Notten, P.H.L. Atomic layer deposition of $\mathrm{LiCoO}_{2}$ thin-film electrodes for all-solid-state Li-Ion micro-batteries. J. Electrochem. Soc. 2013, 160, A3066-A3071. [CrossRef]

93. Miikkulainen, V.; Ruud, A.; Østreng, E.; Nilsen, O.; Laitinen, M.; Sajavaara, T.; Fjellvåg, H. Atomic layer deposition of spinel Lithium manganese oxide by film-body-controlled Lithium incorporation for thin-film Lithium-ion batteries. J. Phys. Chem. C 2014, 118, 1258-1268. [CrossRef]

94. Kozen, A.C.; Pearse, A.J.; Lin, C.-F.; Noked, M.; Rubloff, G.W. Atomic layer deposition of the solid electrolyte LiPON. Chem. Mater. 2015, 27, 5324-5331. [CrossRef]

95. Nisula, M.; Shindo, Y.; Koga, H.; Karppinen, M. Atomic layer deposition of Lithium phosphorus oxynitride. Chem. Mater. 2015, 27, 6987-6993. [CrossRef]

96. Kazyak, E.; Chen, K.-H.; Wood, K.N.; Davis, A.L.; Thompson, T.; Bielinski, A.R.; Sanchez, A.J.; Wang, X.; Wang, C.; Sakamoto, J.; et al. Atomic layer deposition of the solid electrolyte garnet $\mathrm{Li}_{7} \mathrm{La}_{3} \mathrm{Zr}_{2} \mathrm{O}_{12}$. Chem. Mater. 2017, 29, 3785-3792. [CrossRef]

97. Perng, Y.-C.; Cho, J.; Sun, S.Y.; Membreno, D.; Cirigliano, N.; Dunn, B.; Chang, J.P. Synthesis of ion conducting $\mathrm{Li}_{x} \mathrm{Al}_{y} \mathrm{Si}_{z} \mathrm{O}$ thin films by atomic layer deposition. J. Mater. Chem. A 2014, 2, 9566-9573. [CrossRef]

98. Cho, J.; Kim, T.; Seegmiller, T.; Chang, J.P. Elucidating the surface reaction mechanisms during atomic layer deposition of $\mathrm{Li}_{x} \mathrm{Al}_{y} \mathrm{Si}_{z} \mathrm{O}$ by in situ fourier transform infrared spectroscopy. J. Phys. Chem. C 2016, 120, 11837-11846. [CrossRef]

99. Liu, J.; Banis, M.N.; Li, X.; Lushington, A.; Cai, M.; Li, R.; Sham, T.-K.; Sun, X. Atomic layer deposition of Lithium tantalate solid-state electrolytes. J. Phys. Chem. C 2013, 117, 20260-20267. [CrossRef] 
100. Cao, Y.; Meng, X.; Elam, J.W. Atomic layer deposition of $\mathrm{Li}_{x} \mathrm{Al}_{y} \mathrm{~S}$ solid-state electrolytes for stabilizing Lithium-metal anodes. ChemElectroChem 2016, 3, 858-863. [CrossRef]

101. Wang, B.; Liu, J.; Banis, M.N.; Sun, Q.; Zhao, Y.; Li, R.; Sham, T.K.; Sun, X. Atomic layer deposited Lithium silicates as solid-state electrolytes for all solid-state batteries. ACS Appl. Mater. Interfaces 2017. [CrossRef] [PubMed]

102. Wang, X.; Fan, L.; Gong, D.; Zhu, J.; Zhang, Q.; Lu, B. Core-shell Ge@Graphene@TiO 2 nanofibers as a high-capacity and cycle-stable anode for Lithium and sodium ion battery. Adv. Funct. Mater. 2016, 26, 1104-1111. [CrossRef]

103. Lee, T.; Min, S.H.; Gu, M.; Jung, Y.K.; Lee, W.; Lee, J.U.; Seong, D.G.; Kim, B.-S. Layer-by-layer assembly for graphene-based multilayer nanocomposites: Synthesis and applications. Chem. Mater. 2015, 27, 3785-3796. [CrossRef]

104. Wang, X.H.; Guan, C.; Sun, L.M.; Susantyoko, R.A.; Fan, H.J.; Zhang, Q. Highly stable and flexible Li-Ion battery anodes based on $\mathrm{TiO}_{2}$ coated 3D carbon nanostructures. J. Mater. Chem. A 2015, 3, 15394-15398. [CrossRef]

105. Meng, X.B.; Geng, D.S.; Liu, J.; Banis, M.N.; Zhang, Y.; Li, R.Y.; Sun, X.L. Non-aqueous approach to synthesize amorphous/crystalline metal oxide-graphene nanosheet hybrid composites. J. Phys. Chem. C 2010, 114, 18330-18337. [CrossRef]

106. Marichy, C.; Bechelany, M.; Pinna, N. Atomic layer deposition of nanostructured materials for energy and environmental applications. Adv. Mater. 2012, 24, 1017-1032. [CrossRef] [PubMed]

107. Tao, X.; Liu, Y.; Liu, W.; Zhou, G.; Zhao, J.; Lin, D.; Zu, C.; Sheng, O.; Zhang, W.; Lee, H.W.; et al. Solid-state Lithium-sulfur batteries operated at $37^{\circ} \mathrm{C}$ with composites of nanostructured $\mathrm{Li}_{7} \mathrm{La}_{3} \mathrm{Zr}_{2} \mathrm{O}_{12} /$ Carbon foam and polymer. Nano Lett. 2017, 17, 2967-2972. [CrossRef] [PubMed]

108. Zhou, W.; Wang, S.; Li, Y.; Xin, S.; Manthiram, A.; Goodenough, J.B. Plating a dendrite-free Lithium anode with a polymer/ceramic/polymer sandwich electrolyte. J. Am. Chem. Soc. 2016, 138, 9385-9388. [CrossRef] [PubMed]

109. Auvergniot, J.; Cassel, A.; Ledeuil, J.-B.; Viallet, V.; Seznec, V.; Dedryvère, R. Interface stability of argyrodite $\mathrm{Li}_{6} \mathrm{PS}_{5} \mathrm{Cl}$ toward $\mathrm{LiCoO}_{2}, \mathrm{LiNi}_{1 / 3} \mathrm{Co}_{1 / 3} \mathrm{Mn}_{1 / 3} \mathrm{O}_{2}$, and $\mathrm{LiMn}_{2} \mathrm{O}_{4}$ in bulk all-solid-state batteries. Chem. Mater. 2017, 29, 3883-3890. [CrossRef]

110. Létiche, M.; Eustache, E.; Freixas, J.; Demortière, A.; De Andrade, V.; Morgenroth, L.; Tilmant, P.; Vaurette, F.; Troadec, D.; Roussel, P.; et al. Atomic layer deposition of functional layers for on chip 3D Li-ion all solid state microbattery. Adv. Energy Mater. 2017, 7, 1601402. [CrossRef]

111. Park, J.S.; Mane, A.U.; Elam, J.W.; Croy, J.R. Atomic layer deposition of Al-W-Fluoride on $\mathrm{LiCoO}_{2}$ cathodes: Comparison of particle- and electrode-level coatings. ACS Omega 2017, 2, 3724-3729. [CrossRef]

112. Park, J.S.; Mane, A.U.; Elam, J.W.; Croy, J.R. Amorphous metal fluoride passivation coatings prepared by atomic layer deposition on $\mathrm{LiCoO}_{2}$ for Li-Ion batteries. Chem. Mater. 2015, 27, 1917-1920. [CrossRef]

113. Xie, J.; Sendek, A.D.; Cubuk, E.D.; Zhang, X.; Lu, Z.; Gong, Y.; Wu, T.; Shi, F.; Liu, W.; Reed, E.J.; et al. Atomic layer deposition of stable $\mathrm{LiAlF}_{4}$ Lithium ion conductive interfacial layer for stable cathode cycling. ACS Nano 2017, 11, 7019-7027. [CrossRef] [PubMed]

114. Li, X.; Liu, J.; Banis, M.N.; Lushington, A.; Li, R.; Cai, M.; Sun, X. Atomic layer deposition of solid-state electrolyte coated cathode materials with superior high-voltage cycling behavior for Lithium ion battery application. Energy Environ. Sci. 2014, 7, 768-778. [CrossRef]

115. Cho, D.-H.; Jo, C.-H.; Cho, W.; Kim, Y.-J.; Yashiro, H.; Sun, Y.-K.; Myung, S.-T. Effect of residual Lithium compounds on layer $\mathrm{Ni}-\mathrm{Rich} \mathrm{Li}\left[\mathrm{Ni}_{0.7} \mathrm{Mn}_{0.3}\right] \mathrm{O}_{2}$. J. Electrochem. Soc. 2014, 161, A920-A926. [CrossRef]

116. Oh, P.; Ko, M.; Myeong, S.; Kim, Y.; Cho, J. A novel surface treatment method and new insight into discharge voltage deterioration for high-performance $0.4 \mathrm{Li}_{2} \mathrm{MnO}_{3-0} \cdot 6 \mathrm{LiNi}_{1 / 3} \mathrm{Co}_{1 / 3} \mathrm{Mn}_{1 / 3} \mathrm{O}_{2}$ cathode materials. Adv. Energy Mater. 2014, 4, 1400631. [CrossRef]

117. Lotfabad, E.M.; Kalisvaart, P.; Kohandehghan, A.; Cui, K.; Kupsta, M.; Farbod, B.; Mitlin, D. Si nanotubes ALD coated with $\mathrm{TiO}_{2}, \mathrm{TiN}$ or $\mathrm{Al}_{2} \mathrm{O}_{3}$ as high performance Lithium ion battery anodes. J. Mater. Chem. A 2014, 2, 2504-2516. [CrossRef]

118. Li, X.; Liu, J.; Meng, X.; Tang, Y.; Banis, M.N.; Yang, J.; Hu, Y.; Li, R.; Cai, M.; Sun, X. Significant impact on cathode performance of Lithium-ion batteries by precisely controlled metal oxide nanocoatings via atomic layer deposition. J. Power Sources 2014, 247, 57-69. [CrossRef] 
119. Laskar, M.R.; Jackson, D.H.; Guan, Y.; Xu, S.; Fang, S.; Dreibelbis, M.; Mahanthappa, M.K.; Morgan, D.; Hamers, R.J.; Kuech, T.F. Atomic layer deposition of $\mathrm{Al}_{2} \mathrm{O}_{3}-\mathrm{Ga}_{2} \mathrm{O}_{3}$ alloy coatings for $\mathrm{Li}\left[\mathrm{Ni}_{0.5} \mathrm{Mn}_{0.3} \mathrm{Co}_{0.2}\right] \mathrm{O}_{2}$ cathode to improve rate performance in Li-Ion battery. ACS Appl. Mater. Interfaces 2016, 8, 10572-10580. [CrossRef] [PubMed]

120. Liu, J.; Li, X.; Cai, M.; Li, R.; Sun, X. Ultrathin atomic layer deposited $\mathrm{ZrO}_{2}$ coating to enhance the electrochemical performance of $\mathrm{Li}_{4} \mathrm{Ti}_{5} \mathrm{O}_{12}$ as an anode material. Electrochim. Acta 2013, 93, 195-201. [CrossRef]

121. Jung, Y.S.; Cavanagh, A.S.; Riley, L.A.; Kang, S.H.; Dillon, A.C.; Groner, M.D.; George, S.M.; Lee, S.H. Ultrathin direct atomic layer deposition on composite electrodes for highly durable and safe Li-Ion batteries. Adv. Mater. 2010, 22, 2172-2176. [CrossRef] [PubMed]

122. Wang, H.-Y.; Wang, F.-M. Electrochemical investigation of an artificial solid electrolyte interface for improving the cycle-ability of Lithium ion batteries using an atomic layer deposition on a graphite electrode. J. Power Sources 2013, 233, 1-5. [CrossRef]

123. Becker, C.R.; Prokes, S.M.; Love, C.T. Enhanced Lithiation cycle stability of ALD-Coated confined $a$-Si microstructures determined using in situ AFM. ACS Appl. Mater. Interfaces 2016, 8, 530-537. [CrossRef] [PubMed]

124. Li, B.; Yao, F.; Bae, J.J.; Chang, J.; Zamfir, M.R.; Le, D.T.; Pham, D.T.; Yue, H.; Lee, Y.H. Hollow Carbon Nanospheres/Silicon/Alumina core-shell film as an anode for Lithium-ion batteries. Sci. Rep. 2015, 5, 7659. [CrossRef] [PubMed]

125. Hy, S.; Chen, Y.H.; Cheng, H.M.; Pan, C.J.; Cheng, J.H.; Rick, J.; Hwang, B.J. Tabilizing nanosized Si anodes with the synergetic usage of atomic layer deposition and electrolyte additives for Li-ion batteries. ACS Appl. Mater. Interfaces 2015, 7, 13801-13807. [CrossRef] [PubMed]

126. Karg, M.; Lokare, K.S.; Limberg, C.; Clavel, G.; Pinna, N. Atomic layer deposition of silica on carbon nanotubes. Chem. Mater. 2017, 29, 4920-4931. [CrossRef]

127. Kozen, A.C.; Lin, C.-F.; Zhao, O.; Lee, S.B.; Rubloff, G.W.; Noked, M. Stabilization of Lithium metal anodes by hybrid artificial solid electrolyte interphase. Chem. Mater. 2017, 29, 6298-6307. [CrossRef]

128. Smith, A.J.; Burns, J.C.; Zhao, X.M.; Xiong, D.; Dahn, J.R. A high precision coulometry study of the SEI growth in Li/Graphite cells. J. Electrochem. Soc. 2011, 158, A447-A452. [CrossRef]

129. Güneş, F. A direct synthesis of Si-Nanowires on $3 \mathrm{D}$ porous graphene as a high performance anode material for Li-ion batteries. RSC Adv. 2016, 6, 1678-1685. [CrossRef]

130. Bai, Y.; Yan, D.; Yu, C.; Cao, L.; Wang, C.; Zhang, J.; Zhu, H.; Hu, Y.-S.; Dai, S.; Lu, J.; et al. Core-shell $\mathrm{Si} @ \mathrm{TiO}_{2}$ nanosphere anode by atomic layer deposition for Li-ion batteries. J. Power Sources 2016, 308, 75-82. [CrossRef]

131. Shelke, M.V.; Gullapalli, H.; Kalaga, K.; Rodrigues, M.-T.F.; Devarapalli, R.R.; Vajtai, R.; Ajayan, P.M. Facile synthesis of 3D anode assembly with Si nanoparticles sealed in highly pure few layer graphene deposited on porous current collector for long life Li-ion battery. Adv. Mater. Interfaces 2017, 4, 1601043. [CrossRef]

132. Li, Y.; Sun, Y.J.; Xu, G.J.; Lu, Y.; Zhang, S.; Xue, L.G.; Jur, J.S.; Zhang, X.W. Tuning electrochemical performance of Si-based anodes for Lithium-ion batteries by employing atomic layer deposition alumina coating. J. Mater. Chem. A 2014, 2, 11417-11425. [CrossRef]

133. Cheng, X.B.; Zhang, R.; Zhao, C.Z.; Zhang, Q. Toward safe Lithium metal anode in rechargeable batteries: A review. Chem. Rev. 2017, 117, 10403-10473. [CrossRef] [PubMed]

134. Lin, C.-F.; Kozen, A.C.; Noked, M.; Liu, C.; Rubloff, G.W. ALD protection of Li-metal anode surfaces-quantifying and preventing chemical and electrochemical corrosion in organic solvent. Adv. Mater. Interfaces 2016, 3, 1600426. [CrossRef]

135. Kazyak, E.; Wood, K.N.; Dasgupta, N.P. Mproved cycle life and stability of Lithium metal anodes through ultrathin atomic layer deposition surface treatments. Chem. Mater. 2015, 27, 6457-6462. [CrossRef]

136. Guan, D.; Yuan, C. Enhancing the cycling stability of tin sulfide anodes for Lithium ion battery by Titanium oxide atomic layer deposition. J.Electrochem. Energy 2016, 13, 021004. [CrossRef]

137. Guan, D.; Ma, L.; Pan, D.; Li, J.; Gao, X.; Xie, Y.; Qiu, M.; Yuan, C. Atomic layer deposition of alumina coatings onto $\mathrm{SnS}_{2}$ for Lithium-ion battery applications. Electrochim. Acta 2017, 242, 117-124. [CrossRef]

138. Liu, X.; Sun, Q.; Ng, A.M.C.; Djurišić, A.B.; Xie, M.; Dai, B.; Tang, J.; Surya, C.; Liao, C.; Shih, K. An alumina stabilized graphene oxide wrapped $\mathrm{SnO}_{2}$ hollow sphere LIB anode with improved Lithium storage. RSC Adv. 2015, 5, 100783-100789. [CrossRef] 
139. Ahmed, B.; Shahid, M.; Nagaraju, D.H.; Anjum, D.H.; Hedhili, M.N.; Alshareef, H.N. Surface passivation of $\mathrm{MoO}_{3}$ nanorods by atomic layer deposition toward high rate durable Li ion battery anodes. ACS Appl. Mater. Interfaces 2015, 7, 13154-13163. [CrossRef] [PubMed]

140. Wu, Q.-H.; Qu, B.; Tang, J.; Wang, C.; Wang, D.; Li, Y.; Ren, J.-G. An alumina-coated $\mathrm{Fe}_{3} \mathrm{O}_{4}$-Reduced graphene oxide composite electrode as a stable anode for Lithium-ion battery. Electrochim. Acta 2015, 156, 147-153. [CrossRef]

141. Lv, X.; Deng, J.; Sun, X. Cumulative effect of $\mathrm{Fe}_{2} \mathrm{O}_{3}$ on $\mathrm{TiO}_{2}$ nanotubes via atomic layer deposition with enhanced Lithium ion storage performance. Appl. Surf. Sci. 2016, 369, 314-319. [CrossRef]

142. Cao, F.; Xia, X.H.; Pan, G.X.; Chen, J.; Zhang, Y.J. Construction of carbon nanoflakes shell on CuO nanowires core as enhanced core/shell arrays anode of Lithium ion batteries. Electrochim. Acta 2015, 178, 574-579. [CrossRef]

143. Molina Piper, D.; Son, S.-B.; Travis, J.J.; Lee, Y.; Han, S.S.; Kim, S.C.; Oh, K.H.; George, S.M.; Lee, S.-H.; Ban, C. Mitigating irreversible capacity losses from carbon agents via surface modification. J. Power Sources 2015, 275, 605-611. [CrossRef]

144. Loebl, A.J.; Oldham, C.J.; Devine, C.K.; Gong, G.; Atanasov, S.E. Solid electrolyte interphase on Lithium-ion carbon nanofiber electrodes by atomic and molecular layer deposition. J. Electrochem. Soc. 2013, 160, A1971-A1978. [CrossRef]

145. Liu, J.; Wang, B.; Sun, Q.; Li, R.; Sham, T.-K.; Sun, X. Atomic layer deposition of hierarchical CNTs@FePO architecture as a 3D electrode for Lithium-ion and Sodium-ion batteries. Adv. Mater. Interfaces 2016, 3, 1600468. [CrossRef]

146. Xu, K.; He, Y.; Ben, L.; Li, H.; Huang, X. Enhanced electrochemical performance of Si-Cu-Ti thin films by surface covered with $\mathrm{Cu}_{3} \mathrm{Si}$ nanowires. J. Power Sources 2015, 281, 455-460. [CrossRef]

147. Scott, I.D.; Jung, Y.S.; Cavanagh, A.S.; Yan, Y.; Dillon, A.C.; George, S.M.; Lee, S.H. Ultrathin coatings on nano-LiCoO 2 for Li-ion vehicular applications. Nano Lett. 2011, 11, 414-418. [CrossRef] [PubMed]

148. Zhou, Y.; Lee, Y.; Sun, H.; Wallas, J.M.; George, S.M.; Xie, M. Coating solution for high-voltage cathode: $\mathrm{AlF}_{3}$ atomic layer deposition for freestanding $\mathrm{LiCoO}_{2}$ electrodes with high energy density and excellent flexibility. ACS Appl. Mater. Interfaces 2017, 9, 9614-9619. [CrossRef] [PubMed]

149. Pearse, A.J.; Schmitt, T.E.; Fuller, E.J.; El-Gabaly, F.; Lin, C.-F.; Gerasopoulos, K.; Kozen, A.C.; Talin, A.A.; Rubloff, G.; Gregorczyk, K.E. Nanoscale solid state batteries enabled by thermal atomic layer deposition of a Lithium polyphosphazene solid state electrolyte. Chem. Mater. 2017, 29, 3740-3753. [CrossRef]

150. Zhao, J.; Wang, Y. Atomic layer deposition of epitaxial $\mathrm{ZrO}_{2}$ coating on $\mathrm{LiMn}_{2} \mathrm{O}_{4}$ nanoparticles for high-rate Lithium ion batteries at elevated temperature. Nano Energy 2013, 2, 882-889. [CrossRef]

151. Patel, R.L.; Xie, H.; Park, J.; Asl, H.Y.; Choudhury, A.; Liang, X. Significant capacity and cycle-life improvement of Lithium-ion batteries through ultrathin conductive film stabilized cathode particles. Adv. Mater. Interfaces 2015, 2, 1500046. [CrossRef]

152. Waller, G.H.; Brooke, P.D.; Rainwater, B.H.; Lai, S.Y.; Hu, R.; Ding, Y.; Alamgir, F.M.; Sandhage, K.H.; Liu, M.L. Structure and surface chemistry of $\mathrm{Al}_{2} \mathrm{O}_{3}$ coated $\mathrm{LiMn}_{2} \mathrm{O}_{4}$ nanostructured electrodes with improved lifetime. J. Power Sources 2016, 306, 162-170. [CrossRef]

153. Mattelaer, F.; Vereecken, P.M.; Dendooven, J.; Detavernier, C. The influence of ultrathin amorphous ALD alumina and Titania on the rate capability of anatase $\mathrm{TiO}_{2}$ and $\mathrm{LiMn}_{2} \mathrm{O}_{4}$ Lithium ion battery electrodes. Adv. Mater. Interfaces 2017, 4, 1601237. [CrossRef]

154. Kim, J.W.; Travis, J.J.; Hu, E.; Nam, K.-W.; Kim, S.C.; Kang, C.S.; Woo, J.-H.; Yang, X.-Q.; George, S.M.; Oh, K.H.; et al. Unexpected high power performance of atomic layer deposition coated $\mathrm{Li}\left[\mathrm{Ni}_{1 / 3} \mathrm{Mn}_{1 / 3} \mathrm{Co}_{1 / 3}\right] \mathrm{O}_{2}$ cathodes. J. Power Sources 2014, 254, 190-197. [CrossRef]

155. Wise, A.M.; Ban, C.; Weker, J.N.; Misra, S.; Cavanagh, A.S.; Wu, Z.; Li, Z.; Whittingham, M.S.; Xu, K.; George, S.M.; et al. Effect of $\mathrm{Al}_{2} \mathrm{O}_{3}$ coating on stabilizing $\mathrm{LiNi}_{0.4} \mathrm{Mn}_{0.4} \mathrm{Co}_{0.2} \mathrm{O}_{2}$ cathodes. Chem. Mater. 2015, 27, 6146-6154. [CrossRef]

156. Su, Y.; Cui, S.; Zhuo, Z.; Yang, W.; Wang, X.; Pan, F. Enhancing the high-voltage cycling performance of $\mathrm{LiNi}_{0.5} \mathrm{Mn}_{0.3} \mathrm{Co}_{0.2} \mathrm{O}_{2}$ by retarding its interfacial reaction with an electrolyte by atomic-layer-deposited $\mathrm{Al}_{2} \mathrm{O}_{3}$. ACS Appl. Mater. Interfaces 2015, 7, 25105-25112. [CrossRef] [PubMed]

157. Laskar, M.R.; Jackson, D.H.; Xu, S.; Hamers, R.J.; Morgan, D.; Kuech, T.F. Atomic layer deposited MgO: A lower overpotential coating for $\mathrm{Li}\left[\mathrm{Ni}_{0.5} \mathrm{Mn}_{0.3} \mathrm{Co}_{0.2}\right] \mathrm{O}_{2}$ cathode. ACS Appl. Mater. Interfaces 2017, 9, 11231-11239. [CrossRef] [PubMed] 
158. Xiao, B.; Liu, J.; Sun, Q.; Wang, B.; Banis, M.N.; Zhao, D.; Wang, Z.; Li, R.; Cui, X.; Sham, T.K.; et al. Unravelling the role of electrochemically active $\mathrm{FePO}_{4}$ coating by atomic layer deposition for increased high-voltage stability of $\mathrm{LiNi}_{0.5} \mathrm{Mn}_{1.5} \mathrm{O}_{4}$ cathode material. Adv. Sci. 2015, 2, 1500022. [CrossRef] [PubMed]

159. Cho, H.-M.; Chen, M.V.; Alex, C.; MacRae, A.C.; Meng, Y.S. Effect of surface modification on nano-structured $\mathrm{LiNi}_{0.5} \mathrm{Mn}_{1.5} \mathrm{O}_{4}$ spinel materials. ACS Appl. Mater. Interfaces 2015, 7, 16231-16239. [CrossRef] [PubMed]

160. Deng, S.; Xiao, B.; Wang, B.; Li, X.; Kaliyappan, K.; Zhao, Y.; Lushington, A.; Li, R.; Sham, T.-K.; Wang, H.; et al. New insight into atomic-scale engineering of electrode surface for long-life and safe high voltage Lithium ion cathodes. Nano Energy 2017, 38, 19-27. [CrossRef]

161. Zhang, X.; Belharouak, I.; Li, L.; Lei, Y.; Elam, J.W.; Nie, A.; Chen, X.; Yassar, R.S.; Axelbaum, R.L. Structural and electrochemical study of $\mathrm{Al}_{2} \mathrm{O}_{3}$ and $\mathrm{TiO}_{2}$ coated $\mathrm{Li}_{1.2} \mathrm{Ni}_{0.13} \mathrm{Mn}_{0.54} \mathrm{Co}_{0.13} \mathrm{O}_{2}$ cathode material using ALD. Adv. Energy Mater. 2013, 3, 1299-1307. [CrossRef]

162. Xiao, B.; Wang, B.; Liu, J.; Kaliyappan, K.; Sun, Q.; Liu, Y.; Dadheech, G.; Balogh, M.P.; Yang, L.; Sham, T.-K.; et al. Highly stable $\mathrm{Li}_{1.2} \mathrm{Mn}_{0.54} \mathrm{Co}_{0.13} \mathrm{Ni}_{0.13} \mathrm{O}_{2}$ enabled by novel atomic layer deposited $\mathrm{AlPO}_{4}$ cating. Nano Energy 2017, 34, 120-130. [CrossRef]

163. Yan, P.; Zheng, J.; Zhang, X.; Xu, R.; Amine, K.; Xiao, J.; Zhang, J.-G.; Wang, C.-M. Atomic to nanoscale

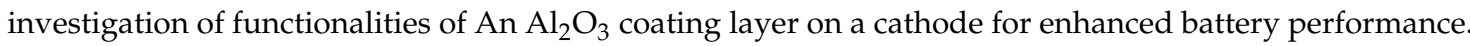
Chem. Mater. 2016, 28, 857-863. [CrossRef]

164. Wang, K.X.; Li, X.H.; Chen, J.S. Surface and interface engineering of electrode materials for Lithium-ion batteries. Adv. Mater. 2015, 27, 527-545. [CrossRef] [PubMed]

165. Riley, L.A.; Van Atta, S.; Cavanagh, A.S.; Yan, Y.; George, S.M.; Liu, P.; Dillon, A.C.; Lee, S.-H. Electrochemical effects of ALD surface modification on combustion synthesized $\mathrm{LiNi}_{1 / 3} \mathrm{Mn}_{1 / 3} \mathrm{Co}_{1 / 3} \mathrm{O}_{2}$ as a layered-cathode material. J. Power Sources 2011, 196, 3317-3324. [CrossRef]

166. Cheng, H.-M.; Wang, F.-M.; Chu, J.P.; Santhanam, R.; Rick, J.; Lo, S.-C. Enhanced cycleabity in Lithium ion batteries: Resulting from atomic layer depostion of $\mathrm{Al}_{2} \mathrm{O}_{3}$ or $\mathrm{TiO}_{2}$ on $\mathrm{LiCoO}_{2}$ electrodes. J. Phys. Chem. C 2012, 116, 7629-7637. [CrossRef] 